\title{
Expedition 325 summary ${ }^{1}$
}

\author{
Expedition 325 Scientists $^{2}$
}

\section{Chapter contents}

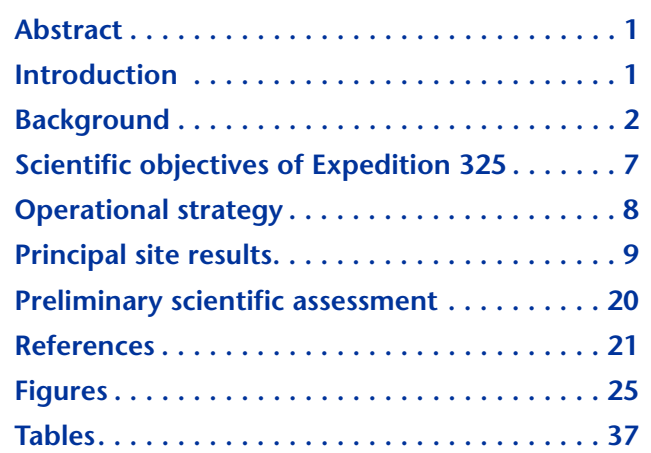

1Expedition 325 Scientists, 2011. Expedition 325 summary. In Webster, J.M., Yokoyama, Y., Cotterill, C., and the Expedition 325 Scientists, Proc. IODP, 325: Tokyo (Integrated Ocean Drilling Program Management International, Inc.). doi:10.2204/iodp.proc.325.101.2011

'Expedition 325 Scientists' addresses.

\section{Abstract}

Integrated Ocean Drilling Program (IODP) Expedition 325, designed to investigate the fossil reefs on the shelf edge of the Great Barrier Reef, was the fourth expedition to utilize a mission-specific platform and was conducted by the European Consortium for Ocean Research Drilling (ECORD) Science Operator (ESO). The objectives of Expedition 325 were to establish the course of sea level change, define sea-surface temperature variations, and analyze the impact of these environmental changes on reef growth and geometry for the region over the period of 20-10 ka. To meet these objectives, a succession of fossil reef structures preserved on the shelf edge seaward of the modern barrier reef were cored from a dynamically positioned vessel in February-April 2010. A total of 34 boreholes across 17 sites were cored in depths ranging from 42.27 to 167.14 meters below sea level (lowest astronomical tide taken from corrected EM300 multibeam bathymetry data). Borehole logging operations in four boreholes provided continuous geophysical information about the drilled strata. The cores were described during the Onshore Science Party (OSP) at the IODP Bremen Core Repository (Germany) in July 2010, where minimum and some standard measurements were made. Preliminary postcruise dating of core catcher samples and initial observations of the cores made during the OSP confirm that coral reef material ranging in age from $>30,000$ to 9,000 calendar years before present (years before $1950 \mathrm{AD}$ ) was recovered during Expedition 325. Further postcruise research on samples taken during the OSP is expected to fulfill the objectives of the expedition.

\section{Introduction}

The timing and courses of deglaciations are considered an essential component for understanding the dynamics of large ice sheets (Lindstrom and MacAyeal, 1993; Denton et al., 2010) and their effects on Earth's isostasy (Nakada and Lambeck, 1987; Lambeck, 1993; Peltier, 1994). Moreover, the disappearance of glacial ice sheets was responsible for dramatic changes in freshwater fluxes to the oceans, which disturbed the thermohaline circulation and hence global climate (e.g., Stocker and Wright, 1991). Coral reefs are excellent sea level indicators. Accurate dating of coral reefs by mass spectrometry is of prime importance for determining the timing of deglaciation events and thus for under- 
standing the mechanisms driving glacial-interglacial cycles and millennial-scale cycles. Furthermore, scleractinian coral colonies can monitor sea-surface temperature and other oceanographic parameters (e.g., salinity and sediment run-off). Fossil corals record past variations in these parameters. Finally, assessing the impact of sea level and paleoclimate changes on fossil reef evolution may represent an important advance in understanding how coral reef systems-in particular the Great Barrier Reef-respond to environmental stress.

\section{Background}

\section{Sea level change as a global climate indicator}

Prior to Integrated Ocean Drilling Program (IODP) Expedition 310 (Tahiti Sea Level), only a few sea level curves based on coral reef records had been accurately dated for the last deglaciation: in Barbados between 19,000 and 8,000 calibrated years before present (cal y BP; years before 1950 AD) (Fairbanks, 1989; Bard et al., 1990a, 1990b; Peltier and Fairbanks, 2006), in New Guinea between 13,000 and 6,000 cal y BP (Chappell and Polach, 1991; Edwards et al., 1993), in Vanuatu between 23,000 and 6 cal y BP (Cabioch et al., 2003), and in Tahiti between 13,750 cal y BP and 2,380 radiocarbon years before present $\left({ }^{14} \mathrm{C}\right.$ y BP) (Bard et al., 1996) (Fig. F1A). Until recently, the Barbados and Vanuatu curves were the only ones to encompass the entire deglaciation. However, these sites, like New Guinea, are located above active subduction zones where tectonic movements can be large and discontinuous. Therefore, reconstructed sea levels may be biased by variations in the rate of tectonic uplift and/or abrupt coseismic vertical motions. Also, Barbados is under the influence of glacial isostatic adjustment because of the waxing and waning of the North American ice sheet (Lambeck et al., 2002; Milne et al., 2009). Hence, there is a clear need to study past sea level changes in tectonically stable regions (or in areas where vertical crustal deformation is slow and/or regular) located far away from former ice-covered regions. The expeditions linked to IODP Proposal 519 (Expedition 310, Tahiti Sea Level, and Expedition 325, Great Barrier Reef Environmental Changes [GBREC]) aim to provide the most comprehensive deglaciation curves from tectonically stable regions by conducting offshore drilling of fossil coral reefs now preserved at 40-120 m below present sea level. Expedition 310 was successfully completed in 2005 (offshore phase) and 2006 (Onshore Science Party) (Camoin et al., 2007).
The Barbados record suggested that the last deglaciation was characterized by three brief periods of accelerated melting superimposed on a smooth and continuous rise of sea level with no reversals (Fig. F1A). These so-called meltwater pulse (MWP) events19ka-MWP (Yokoyama et al., 2000; Clark et al., 2004; DeDeckker and Yokoyama 2009; Hanebuth et al., 2009), MWP-1A, and MWP-1B ( 13,800 and 11,300 cal y BP; Fairbanks, 1989; Bard et al., 1990)—were interpreted to be a consequence of massive inputs of continental ice $(\sim 40-50 \mathrm{~mm} / \mathrm{y}$ in sea level rise that is roughly equivalent to annual discharge rates of $16,000 \mathrm{~km}^{3}$ for MWP-1A). Originally, MWP-1A was thought to correspond to a short and intense cooling between 14,100 and 13,900 cal y BP in the Greenland ice core records (Johnsen et al., 1992; Grootes et al., 1993) and therefore to postdate the initiation of the Bølling-Allerød warm period at $\sim 14,800 \mathrm{cal}$ y BP (Broecker, 1992). However, cumulative evidence from far-field sites suggests that the timing of MWP$1 \mathrm{~A}$ was slightly older than originally proposed (e.g., 14,600-14,700 cal y BP; Hanebuth et al., 2000; Webster et al., 2004); this has been confirmed by the Expedition 310 Tahiti sea level record (Deschamps et al. 2009, submitted).

The apparent sea level jump evident at $\sim 11,000 \mathrm{cal} \mathrm{y}$ BP in the coral record obtained from Huon Peninsula, Papua New Guinea (Edwards et al., 1993), lags MWP-1B by a few centuries compared to the coral record observed at Barbados (Fig. F1A). Two of the inferred meltwater pulses (MWP-1A and MWP-1B) may have induced reef-drowning events (Blanchon and Shaw, 1995). Two "give-up" reef levels have been reported at 90-100 and 55-65 meters below sea level (mbsl) on the Mayotte foreslopes (Comoro Islands) and have been related to MWP-1A and MWP-1B, respectively (Dullo et al., 1998), with similar features recorded in the Caribbean (MacIntyre et al., 1991; Grammer and Ginsburg, 1992). In contrast, the continuous coral record obtained from onshore Tahiti suggests that there are no major changes in the rate of sea level rise during the time of the inferred postYounger Dryas (YD) meltwater pulse (MWP-1B) (Lambeck et al., 2002; Bard et al., 2010). A third Acropora reef-drowning event at $\sim 7600$ cal y BP was reported by Blanchon and Shaw (1995).

Thus, there are still uncertainties about the general pattern of sea level rise during the last deglaciation, including the duration and amplitude of the maximum lowstand during the Last Glacial Maximum (LGM) and potential links between increased glacial meltwater and accelerated sea level rise (Broecker, 1990). Furthermore, sawtooth sea level fluctuations between 19,000 and 15,280 cal y BP (Locker et al., 1996; Yokoyama et al., 2000, 2001c, 2006b); the pre- 
cise timing, rate, and amplitude of MWP-1A; and a sea level variation coeval with climatic change around 11,000 cal y BP are still controversial topics (Lambeck et al., 2002).

Obtaining direct sea level information based on coral reef records older than the last glacial is difficult, and few studies have been reported. The Expedition 310 Tahiti coral record extends to before the last interglacial and provides important insights into the climate system during the penultimate deglaciation (Thomas et al., 2009; Fujita et al., 2010). Offshore drilling at the shelf edge of the Great Barrier Reef (GBR) will provide paleoclimate and sea level records extending into marine isotope Stage (MIS) 3 and beyond.

Sea level compilations indicate that local sea level histories varied considerably around the world in relation to both the postglacial redistribution of water masses and a combination of local processes (Lambeck, 1993; Peltier, 1994; Yokoyama et al., 2001b, 2001c; Lambeck et al., 2003, 2006; Milne et al., 2009), although significant deviations between model predictions and field data have been noted for several regions (Camoin et al., 1997). Post-LGM sea level changes at far-field sites provide basic information regarding the melting history of continental ice sheets and the rheological structure of Earth. The effect of hydro-isostasy on local sea level will depend on the size of the adjacent landmass; near small islands, the addition of meltwater will produce a small differential response between the island and the seafloor, whereas the meltwater load will produce significant differential vertical movement between larger islands (or continental margins) and the seafloor (Nakada, 1986; Yokoyama et al., 1996). Thus there is a need to establish the relative magnitudes of hydro-isostatic effects at two ideal sites, one on an oceanic island and another on a continental margin, located at a considerable distance from the major former ice sheets. It is essential that both sites are tectonically stable throughout the time period proposed for the investigation so that the proposed Northern and Southern Hemisphere deglaciation curves from Barbados and New Guinea can be rigorously tested. Tahiti (Expedition 310, completed in 2006) and the GBR (IODP Expedition 325, completed in 2010) are ideal locations in which to perform these tests.

\section{Climatic and oceanographic changes during the last deglaciation}

The Quaternary period of Earth's history is marked by major cyclical changes in global climate reflected in the growth and decay of high-latitude ice sheets. We are currently in a relatively warm interglacial fol- lowing the LGM, which occurred around 21,000 cal y BP (Yokoyama et al., 2000; Mix et al., 2001). These glacial-interglacial climate oscillations are related to cyclical changes in the distribution of incoming solar radiation due to variations in Earth's orbit around the sun (so-called "Milankovich cycles"). However, it is also clear that strong feedbacks within the earth system operate to amplify and modify the initial insolation-forced changes. Understanding the nature of these feedbacks and the mechanisms through which they influence the timing, rates, and magnitude of climate change remain outstanding issues in climate science.

In this context, the tropical oceans play a crucial role in modulating global climate on glacial-interglacial to interannual (i.e., El Niño Southern Oscillation [ENSO]) timescales. One of the key objectives of Expedition 325 was to elucidate the timing, magnitude, and mechanisms of tropical climate change across a major climate transition-namely, from the peak of the last glaciation (the LGM) to the relative warmth of the early Holocene. Paleodata indicate that the mean global surface temperature during the LGM was several degrees cooler than it is at present (Mix et al., 2001). However, there were large latitudinal differences in the magnitude of this cooling, with the tropics in general showing less cooling difference (with respect to preindustrial temperatures) than the high latitudes. Estimates of tropical sea-surface temperatures (SSTs) based on proxies in deep-sea sediment cores now indicate a mean LGM cooling of $\sim 2^{\circ} \mathrm{C}$ compared to the present, with significant regional variations (MARGO Project Members, 2009; Otto-Bliesner et al., 2009) that include a $\sim 3^{\circ} \mathrm{C}$ cooling in the western sector of the Western Pacific Warm Pool (WPWP) (e.g., Linsley et al., 2010) (Fig. F1B). At a few sites, late-glacial age corals (although not LGM) have been used to estimate cooling (Guilderson et al., 1994; McCulloch et al., 1996; Beck et al., 1997; Gagan et al., 2000). Some of these estimates are similar to those derived from deep-sea sediments, whereas others indicate larger differences (e.g., up to $4^{\circ}-6^{\circ} \mathrm{C}$ cooling). Resolving the inconsistencies between proxy-based reconstructions remains an important priority; subtle diagenesis of some coral samples (e.g., Allison et al., 2005), possible changes in oceanic Sr/Ca affecting coral SST reconstructions (e.g., Stoll and Schrag, 1998; Martin et al., 1999), possible seasonal biases in climate reconstruction from deep-sea sediments, and real differences in regional climate are all possible contributing factors.

The main transition from glacial to interglacial climate occurred in the interval 19,000-9,000 cal y BP. However, the rise in temperature (and sea level) was 
not simple and smooth, at least regionally. Greenland ice cores, as well as North Atlantic deep-sea sediment records, suggest that there was a severe climate reversal during the course of the last deglaciation around 12,000-13,000 cal y BP during the YD (Fig. F1A). Outside the North Atlantic region, diverse paleoclimate evidence suggests synchronous climate events were widespread in the Northern Hemisphere (e.g., Wang et al., 2001; Yuan et al., 2004; Yokoyama et al., 2006a). However, until recently there was sparse evidence for the YD in the tropics. A coral Sr/Ca-based SST reconstruction from Vanuatu was used to suggest that SST during the YD was $\sim 4^{\circ} \mathrm{C}$ cooler (Corrège et al., 2004). Fossil coral records from Expedition 310 in Tahiti also captured $\sim 3^{\circ} \mathrm{C}$ cooling (Asami et al., 2009) and oceanic environmental change during the YD (Inoue et al., 2010). More recently, Griffiths et al. (2010) made paired measurements of calcite $\delta^{18} \mathrm{O}$ and fluid inclusion $\delta^{18} \mathrm{O}$ in stalagmites from southern Indonesia to estimate air temperatures $\sim 6^{\circ} \mathrm{C}$ cooler during the YD. The same stalagmite $\delta^{18} \mathrm{O}$ records indicate that the Indonesian-Australian monsoon was stronger during the YD, in contrast to the weaker YD monsoon recorded by stalagmite $\delta^{18} \mathrm{O}$ records from China (e.g., Yuan et al., 2004). It is important to acknowledge that some of these stalagmite- and coral-based reconstructions of tropical temperatures show YD cooling that is significantly greater than that estimated from deep-sea sediment cores.

Recent studies in the tropical western Pacific have documented Holocene climatic variations, including $\sim 0.5^{\circ}-1^{\circ} \mathrm{C}$ warmer SSTs in the GBR and WPWP during the early middle Holocene, based on analysis of $\mathrm{Sr} / \mathrm{Ca}$ in corals and $\mathrm{Mg} / \mathrm{Ca}$ in planktonic foraminifera (Gagan et al., 1998, 2004; Stott et al., 2004; Linsley et al., 2010), and parallel analyses of $\delta^{18} \mathrm{O}$ indicate that the surface ocean in the WPWP freshened through the Holocene. Coral, lake, and geoarchaeological evidence suggest that ENSO variability was substantially reduced in the early to middle Holocene (e.g., Sandweiss et al., 1996; Rodbell et al., 1999; Tudhope et al., 2001; Moy et al., 2002; McGregor and Gagan, 2004), a finding that challenges state-ofthe-art ocean-atmosphere general circulation models, which, for the most part, reconstruct more modest changes in ENSO for this interval (e.g., Liu et al., 2000; Otto-Bliesner et al., 2003; Brown et al., 2008). New speleothem $\delta^{18} \mathrm{O}$ records from southern Indonesia also suggest that monsoonal rainfall was weaker during the early Holocene (Griffiths et al., 2009), and a coral record from Expedition 310 in Tahiti suggests local SSTs may have been cooler than they are at present (DeLong et al., 2010).
Given the continued uncertainties in constraining the full range of tropical western Pacific climate and the importance of this region to global climate, additional paleodata are required. Some of the most debated points are

- The relationship of the mean temperature and size of the WPWP to global climate and interannual ENSO variability since the LGM,

- The precise dating and quantification of SST and salinity change and variability during the last deglaciation, and

- The extent of the early to mid-Holocene thermal maximum in the tropical western Pacific.

New approaches to these long-standing challenges will be provided by the work done during and after Expedition 325 at the GBR.

\section{The Great Barrier Reef: its suitability, previous results, and promise}

The GBR is the largest epicontinental reef system on Earth, extending $2000 \mathrm{~km}$ in a northwest-southeast direction along the northeast coast of Queensland (Australia) (Davies et al., 1989) (Fig. F2). The origin of this morphologically and biologically important sedimentary system is poorly constrained, with ages of $<500,000 \mathrm{y}$ assigned to the initiation of the northern GBR system (McKenzie et al., 1993; Davies and Peerdeman, 1998; International Consortium, 2001; Webster and Davies, 2003; Braithwaite et al., 2004) and, more recently, ages between 670,000 and 560,000 y assigned to the southern GBR (Dubois et al., 2008).

The northern, central, and southern GBR define ideal sites for the evaluation of sea level changes during the period from 20,000 to 8,000 cal y BP. Reefs on the shelf edge east of Cooktown (Australia) form the semicontinuous outer barrier of the northern GBR. In this area, as well as in the far northern GBR, the reef is narrow with ribbon reefs on its eastern edge and extensive coastal fringing reefs and patch reefs. In the south, the GBR broadens, with patch reefs separated by open water or narrow channels. On the outer shelf east-northeast of Townsville (Australia), modern reefs form a line of pinnacles seaward of the main reef edge with lateral growth on the windward margin. South of $15^{\circ} 30^{\prime} \mathrm{S}$, the reefs are generally $\geq 30 \mathrm{~km}$ offshore and reach $100 \mathrm{~km}$ offshore at $22^{\circ} 30^{\prime} \mathrm{S}$. Farther south, the shelf widens considerably to $>200 \mathrm{~km}$. East of Mackay (Australia), the modern reefs form a complex series of flood-tide deltaic reefs (i.e., Pompey Complex; Hopley, 2006). The coastal lagoon between the main GBR reef tract and the mainland has a maximum depth of $145 \mathrm{~m}$ but rarely exceeds $60 \mathrm{~m}$ (Wolanski, 1982). 
Studies of the GBR (McKenzie et al., 1993; Davies and Peerdeman, 1998) focused on the areas southeast of Townsville and east of Cooktown and defined the morphologic shape of the outer reef and upper continental slope, as well as the geological origin of the GBR itself. Based on high-resolution seismic profiles of the fore reef section in front of the GBR, Feary et al. (1993; in McKenzie et al., 1993) recognized three seismic megasequences that define a clearly aggradational upper sequence (0-490 ms twoway traveltime), a transitional middle sequence (490-555 ms two-way traveltime), and a progradational lower sequence (below $555 \mathrm{~ms}$ two-way traveltime). In 1991, indirect evidence that the GBR is very young, having initiated during MISs 9-11 (McKenzie et al., 1993; Davies and Peerdeman, 1998), was recovered during Ocean Drilling Program (ODP) Leg 133.

In 1995, a new phase of drilling at Boulder Reef $\left(15^{\circ} 23.944^{\prime} \mathrm{S}, 145^{\circ} 26.182^{\prime} \mathrm{E} ; 86 \mathrm{~m}\right.$ core depth below seafloor [CSF-A]) and Ribbon Reef $5\left(15^{\circ} 22.40^{\prime} \mathrm{S}\right.$, $145^{\circ} 47.149^{\prime} \mathrm{E} ; 210 \mathrm{~m}$ CSF-A), using a reef-mounted jack-up platform, revealed that the northern GBR is $\sim 100 \mathrm{~m}$ thick and rests on a subreef subtropical red coralline algal facies that, in turn, overlies a deepwater temperate grainstone facies (Davies and Peerdeman, 1998; International Consortium, 2001). Strontium isotope and magnetostratigraphic data from the base of the Pleistocene coral reef sequence confirmed that the origin of the GBR is very young, perhaps <500,000 y (International Consortium, 2001; Webster and Davies, 2003; Braithwaite et al., 2004). Detailed stratigraphic and sedimentary facies analysis of the $210 \mathrm{~m}$ long Ribbon Reef 5 drill core shows that the upper part of the platform is composed of cycles of transgressional cool-water coralline-dominated carbonates topped by shallow-water highstand coral reefs (Webster and Davies, 2003; Braga and Aguirre, 2004). However, the Holocene reef does not show this cyclic sedimentary couplet, as it is coral dominated from its inception at $8000 \mathrm{cal} \mathrm{y} \mathrm{BP.}$

Previous sedimentological and geophysical studies on the shelf edge have identified a succession of subsea morphologic structures interpreted as drowned reefs at 100, 90, 60-50, and 40-35 mbsl (Carter and Johnson, 1986; Harris and Davies, 1989; Larcombe et al., 1995; Hopley, 2006; Beaman et al., 2008), especially in the following four areas:

1. Cooktown shelf and slope (Ribbon Reef),

2. Cairns shelf and slope (Grafton Passage, Flora Passage, and Noggin Pass),

3. Townsville shelf and slope (Bowl and Viper Reef), and

4. Mackay shelf and slope (Hydrographer's Passage).
For example, a series of drowned linear reefs and lagoons occupy specific depths over at least a $30 \mathrm{~km}$ stretch on the outer continental shelf in the vicinity of Hydrographer's Passage in the southern GBR region.

Based on the R/V Southern Surveyor cruise in September-October 2007, Webster et al. (2008a, 2008b) identified five primary drill site transects from three of these key regions on the Cooktown, Cairns, and Mackay shelf edges (Fig. F2).

\section{Proposed drill sites}

\section{Available site survey data for the Great Barrier Reef}

The proposed drill sites on the GBR are distributed in three distinct regions (Fig. F2): offshore Cooktown (Ribbon Reef 5 and 3), offshore Cairns (Noggin Pass), and McKay shelf (Hydrographer's Passage).

From previous site survey data (described in detail in the June 2007 preliminary report to the Environmental Protection and Safety Panel [EPSP] and recently synthesized by Beaman et al., 2008), it was clear that a succession of barrier reefs occupy the outer shelf between 100 and 40 mbsl with terrace features at $\sim 110-80$ mbsl along much of the GBR. These features have not previously been investigated in detail. For example, with the exception of the Ribbon Reef 5 region, only limited systematic high-resolution swath bathymetry mapping, imaging, or sampling had ever been attempted. However, it is clear that these submerged reef structures have the potential to provide unique information about the nature of sea level and climatic change offshore eastern Australia and important information about their role as habitats and substrates for present-day biological communities.

Prior to Expedition 325, proponents led a site survey cruise to gather the most comprehensive data set ever collected from the GBR shelf edge (Webster et al., 2008b). The cruise on the Southern Surveyor acquired the remaining site survey information needed for IODP drilling operations in the GBR. Four study sites (Ribbon Reef, Noggin Pass, Viper Reef, and Hydrographer's Passage) were mapped along the Queensland margin where the approximate location of submerged reefs is known. The data types acquired and submitted to the IODP Site Survey Database were

- EM300 swath bathymetry and backscatter;

- Subbottom sparker and Topas PS18 seismic reflection profiles;

- High-resolution underwater stereoscopic images and high-resolution multibeam bathymetry 
acquired onboard a state-of-the-art Autonomous Underwater Vehicle (AUV);

- Continuous measurements establishing the present-day oceanographic conditions on the shelf edge, using the AUV's onboard Seabird concentration/temperature/depth recorder; and

- Dredged rock samples from the tops of the shelfedge reefs, acquired using a standard rock dredge and a Smith-McIntyre sediment grab.

These data were used to define specific drill targets for Expedition 325 drilling operations (see "Operational strategy" for proposed transect locations and available site survey information).

\section{Summary of 2007 Great Barrier Reef site survey data for the proposed sites \\ Mackay shelf, Hydrographer's Passage (transects HYD- 01C and HYD-02A)}

EM300 swath mapping of the Hydrographer's Passage survey area covers $810.68 \mathrm{~km}^{2}$. Based on a detailed examination of all available site survey data, we proposed to drill two transects of holes across the best developed fossil reef features, one in the northwest (transect HYD-01C) and the other in the southeast (transect HYD-02A). See Figure F2 for the general location and Figures F3 and F4 in this chapter and F1 in the "Transect HYD-01C" chapter for detailed maps of transect HYD-01C. Figures F5 and F6 in this chapter and F1 in the "Transect HYD-02A" chapter show detailed maps of transect HYD-02A.

Site survey data from the northwest sector of Hydrographer's Passage illustrate the succession of morphological features that define transect HYD-01C:

- A double-fronted barrier reef 200 and $100 \mathrm{~m}$ wide separated by a lagoon $2 \mathrm{~km}$ wide and as deep as 70 $\mathrm{m}$; barrier reefs occur at 55-51 mbsl. In some regions, the lagoon is characterized by prominent subbottom reflectors, as well as $50 \mathrm{~m}$ wide patch reefs rising to $55 \mathrm{mbsl}$.

- A steeply sloping $500 \mathrm{~m}$ wide terrace with a sharp break in slope marking the $80 \mathrm{mbsl}$ reef feature.

- A complex $1 \mathrm{~km}$ wide lagoon and reef terrace system. The lagoon at $87-85 \mathrm{mbsl}$ is as wide as $600 \mathrm{~m}$ with numerous prominent subbottom reflectors. Seaward, the lagoon grades into a $400 \mathrm{~m}$ wide relatively flat terrace and a sharp break in slope that marks the 90 mbsl reef feature.

- A $700 \mathrm{~m}$ wide lagoon and reef pinnacle system. The lagoon, characterized by prominent subbottom reflectors, is $300 \mathrm{~m}$ wide and at $95 \mathrm{mbsl}$. The lagoon grades seaward into a dense system of patch reefs or pinnacles $\sim 30-40 \mathrm{~m}$ across that range between 95 and 97 mbsl.
- A major break in slope that defines the $100 \mathrm{mbsl}$ reef feature also has a series of smaller seaward pinnacles and terraces interpreted as reefs at 110 and $120 \mathrm{mbsl}$.

- A gentle upper slope characterized by >160 ms (two-way traveltime) of fore reef slope sediments.

Site survey data from the southeast of Hydrographer's Passage illustrate the succession of morphological features that define transect HYD-02A:

- A submerged reef shoal $600 \mathrm{~m}$ wide at $31 \mathrm{mbsl}$ with well-developed landward and seaward terraces at $40 \mathrm{mbsl}$.

- A double-fronted barrier reef 250 and $150 \mathrm{~m}$ wide separated by a lagoon $2.5 \mathrm{~km}$ wide and as deep as $55 \mathrm{~m}$; barrier reefs occur at 54-56 mbsl. The lagoon is characterized by numerous prominent subbottom reflectors and partially buried patch reefs, which become more dense seaward between 70 and $60 \mathrm{mbsl}$.

- A steep slope $400 \mathrm{~m}$ seaward of the reef at $50 \mathrm{mbsl}$ defined by a series of smaller pinnacles and terraces interpreted as distinct reefs at 65,70 , and 80 mbsl.

- A complex $2.3 \mathrm{~km}$ wide lagoon, reef pinnacle, and terrace system between 90 and $100 \mathrm{mbsl}$. The lagoon is $2 \mathrm{~km}$ wide and up to $102 \mathrm{~m}$ deep with prominent subbottom reflectors that are only interrupted by significant breaks in slope that define the 90 and 100 mbsl reef features.

- A major break in slope that occurs at 103 mbsl and defines the 100 mbsl reef feature, with a series of smaller pinnacles and terraces interpreted as reef features at $110 \mathrm{mbsl}$.

- A prominent $70 \mathrm{~m}$ wide reef terrace observed at 128-126 mbsl, interpreted to be the LGM reef.

- A gentle upper slope characterized by $>160 \mathrm{~ms}$ (two-way traveltime) of fore reef slope sediments.

\section{Offshore Cooktown, Ribbon Reef 5 and 3 (transects RIB- 01C and RIB-02A)}

EM300 swath mapping of the Ribbon Reef survey area covers $1609.87 \mathrm{~km}^{2}$. The Ribbon Reef 5 area was also surveyed by Webster and colleagues in 2005 using a Reson $8101(240 \mathrm{kHz})$ swath mapping system and Datasonics CAP-6600 Chirp $3.5 \mathrm{kHz}$ subbottom profiler (Beaman et al., 2008). Based on a detailed examination of all available site survey data (multibeam, backscatter, seismic profiles, AUV imagery, and bottom samples), the initial plan was to drill two transects of holes during Expedition 325 across the best developed fossil reef features, one off Ribbon Reef 5 (transect RIB-01C) and another off Ribbon Reef 3 (transect RIB-02A). However, only one 
transect (RIB-02A) was drilled, and so only the details regarding that particular transect are included in this report. See Figure F2 for the general location and Figures F7 and F8 in this chapter and F1 in the "Transect RIB-02A" chapter for detailed maps.

Site survey data seaward of modern Ribbon Reef 3 illustrate the succession of morphological features that define transect RIB-02A:

- A modern reef-front talus zone that extends to 44 mbsl;

- A well-developed reef on the shelf lying parallel to the shelf break at $47 \mathrm{mbsl}$ that defines the $50 \mathrm{mbsl}$ reef feature;

- A gently sloping terrace $\sim 330 \mathrm{~m}$ wide at $80-55$ mbsl, with prominent subbottom reflectors visible;

- A submerged reef observed at $80 \mathrm{mbsl}$, characterized by a subtle raised rim 1-2 $\mathrm{m}$ high, that defines the $70 \mathrm{mbsl}$ reef feature; and

- The main shelf break at $105 \mathrm{mbsl}$, characterized by a $3-5 \mathrm{~m}$ raised rim that forms the $100 \mathrm{mbsl}$ reef feature. Below $500 \mathrm{mbsl}$, the upper slope is deeply incised by canyons that extend down into the Queensland Trough.

\section{Offshore Cairns, Noggin Pass (transect NOG-01B)}

EM300 swath mapping of the Noggin Pass survey area covered $1243.27 \mathrm{~km}^{2}$. See Figure F2 for the general location and Figures F9 and F10 in this chapter and F1 in the "Transect NOG-01B" chapter for detailed maps.

Available site survey data seaward of modern Noggin Reef illustrate the succession of morphological features that define transect NOG-01B:

- A double-fronted barrier reef 250 and $90 \mathrm{~m}$ wide separated by a lagoon $80 \mathrm{~m}$ wide; barrier reefs occur at 44-42 mbsl.

- A lagoon as wide as $250 \mathrm{~m}$ at a depth of 57-54 mbsl with reef pinnacles $\sim 50 \mathrm{~m}$ wide and rising to a depth of 56 mbsl. The lagoon is characterized by prominent subbottom reflectors and is fronted by a discontinuous barrier, which tops at $55 \mathrm{mbsl}$ and represents the $50 \mathrm{mbsl}$ reef feature.

- A gently sloping terrace $\sim 450 \mathrm{~m}$ wide at 80-60 mbsl. A break in slope at the edge of this terrace marks the 80 mbsl reef feature.

- A gently sloping terrace $\sim 140 \mathrm{~m}$ wide at 99-91 mbsl. A distinct break in slope at the edge of this terrace marks the reef feature at 100 mbsl.

- A narrow $50 \mathrm{~m}$ terrace at $108 \mathrm{mbsl}$ and a main shelf break that forms the 110 mbsl reef feature.
- A gentle upper slope characterized by $>100 \mathrm{~ms}$ (two-way traveltime) of fore reef slope sediments. Below $250 \mathrm{mbsl}$, the upper slope is deeply incised by a well-developed canyon system that extends down to $1400 \mathrm{~m}$ in the Queensland Trough.

\section{Scientific objectives of Expedition 325}

\section{To establish the course of postglacial sea level rise at the Great Barrier Reef.}

The first objective of Expedition 325 was to establish the course of postglacial sea level rise for the GBRspecifically, to define the exact shape of the deglaciation curve for the period from 20 to $10 \mathrm{cal}$ y BP. The expected results will achieve the following:

- Assess the maximum sea level drop during the LGM and establish the timing of its termination;

- Assess the validity, timing, and amplitude of Meltwater Pulse (MWP) events (e.g., 19 ka-MWP, MWP-1A, and MWP-1B);

- Prove or disprove the sawtooth pattern of sea level rise during the last deglaciation (Locker et al., 1996); and

- Test glacio-hydroisostatic modeling-predicted sea level based on different ice and rheological models.

The reconstruction of sea level curves relies on the absolute dating of in situ corals and other reef-building biota provided by radiometric methods (U-series by thermal ionization mass spectrometry and multicollector inductively coupled plasma-mass spectrometry; ${ }^{14} \mathrm{C}$ by accelerator mass spectrometry) and paleobathymetric information deduced from biological communities (corals, algae, benthic foraminifera, and mollusks) that live in a sufficiently narrow or specific depth range to be useful as absolute sea level indicators.

\section{To define sea-surface temperature variations for the region over the period 20 to $10 \mathrm{ka}$.}

The second objective of Expedition 325 was to define sea-surface temperature (SST) variations for the region over the period from 20 to $10 \mathrm{ka}$ to better understand the following:

- The regional variation of SSTs in the southwest Pacific,

- The climatic variability and the identification of specific phenomena such as El Niño Southern Oscillation (ENSO), 
- The global variation and relative timing of postglacial climate change in the Southern and Northern Hemispheres,

- The regional variation of SSTs in the tropical southwest Pacific; and

- Climatic variability and specific phenomena such as ENSO.

Methods include stable isotope $\left(\delta^{18} \mathrm{O}\right)$ and trace element analyses $(\mathrm{Sr} / \mathrm{Ca}$ ratios by inductively coupled plasma spectroscopy and thermal ionization mass spectrometry) based on high-resolution (i.e., monthly) sampling of massive coral colonies. Coupled analyses of $\delta^{18} \mathrm{O}$ and $\mathrm{Sr} / \mathrm{Ca}$ on the same sample may yield estimates of both temperature and salinity (McCulloch et al., 1996). $\delta^{13} \mathrm{O}$ measurements, coupled with of $\delta^{18} \mathrm{O}$ in coral skeletons, will provide information on other parameters (e.g., solar variations or coral metabolic processes). Geochemical methods will be coupled with measurements and analyses of density band widths and microstructural variations in the coral skeletons.

\section{To analyze the impact of sea level changes on reef growth and geometry.}

The third objective of Expedition 325 was to analyze the impact of sea level change on reef growth and geometry, especially the following:

- Glacial meltwater phases (identification of reef deepening and/or drowning events),

- The morphological and sedimentological evolution of the fore reef slopes (highstand versus lowstand processes),

- The modeling of reef building, and

- Environmental changes during reef development.

Numerical models (e.g., CARB3D, DIONISIS) simulating reef building will be used to study the effect of abrupt sea level rise events on reef geometry and to assess qualitatively the effect of sea level fluctuations on reef structure shape and composition, as well as age-depth relationships.

Work done during and after Expedition 325 will provide the opportunity to better constrain the postglacial sea level history (Peltier, 1994; Fleming et al., 1998; Okuno and Nakada, 1999; Lambeck et al., 2002) by documenting the LGM lowstand in wellstudied cores in the far-field and by comparing MWP-1A in the Pacific and Atlantic. Furthermore, the study of LGM and early postglacial coral material should allow calculation of the first Sr/Ca-SSTs in the Pacific, which will supplement the Barbados SST history sample (Guilderson et al., 1994) and the results of Expedition 310 for Tahiti (Camoin et al., 2007; Asami et al., 2010; DeLong et al., 2010; Inoue et al., 2010).

\section{Operational strategy}

The Barbados offshore drilling (Fairbanks, 1989) demonstrated that the reef sequences corresponding to the last deglaciation developed on slopes forming discontinuous successive terraces of various lateral extent and stratigraphic thicknesses Therefore, to recover the entire postglacial reef sequence, successive reef terraces that occur seaward of the living barrier reef must be drilled.

Our detailed analysis of the combined GBR site survey data have demonstrated the occurrence of successive reef features at depths between 130 and 25 mbsl that correspond to potential drilling targets. Thus, at each geographic location, we cored a transect of several holes to recover the entire postglacial reef sequence. Initial results obtained from Expedition 310 confirm that this drilling strategy is sound (Camoin et al., 2007).

Based on the results of seismic, bathymetric, and sample data acquired during the Southern Surveyor cruise in September-October 2007, four transects located within three geographical areas (Fig. F2) were drilled during Expedition 325: Hydrographer's Passage (2 transects), Noggin Pass (1 transect), and Ribbon Reef 3 (1 transect). Depths at these locations ranged from 47.27 to 167.14 mbsl (lowest astronomical tide taken from corrected EM300 data).

The exact location of drill holes was determined during the expedition by checking the nature and morphology of the seafloor with a through-pipe camera system. This enabled the protection of benthic biota from any disturbance during drilling. Following the completion of each hole, the cored lithologies were assessed by the Co-Chief Scientists and onboard sedimentologists to refine the position of the next hole. All holes were sited within a $125 \mathrm{~m}$ radius around the proposed drilling sites approved by the EPSP and within the transect boundaries given in the research permit issued by the Great Barrier Reef Marine Park Authority. The general locations and enlargements of groupings of sites for the holes in transects HYD01C, HYD-02A, RIB-02A, and NOG-01B are shown, respectively, in Figures F4 in this chapter and F1 in the "Transect HYD-01C" chapter, F6 in this chapter and F1 in the "Transect HYD-02A" chapter, F8 in this chapter and F1 in the "Transect RIB-02A" chapter, and F10 in this chapter and F1 in the "Transect NOG-01B" chapter. 


\section{Principal site results}

Cores were recovered from 34 holes across 17 sites (M0030-M0058) (Table T1) along the four transects, with a conventionally calculated recovery of $26.6 \%$. Hole depths ranged from 47.27 to 167.11 mbsl (lowest astronomical tide taken from corrected EM300 data), and cores were recovered from 42.27 to 208.5 mbsl. Four transects located within three geographical areas (Fig. F2) were drilled during Expedition 325: Hydrographer's Passage (2 transects; north and south), Noggin Pass (1 transect), and Ribbon Reef (1 transect). Borehole geophysical wireline logging was conducted at four holes.

Because of space limitations on the Greatship Maya, only limited analysis of the cores was performed offshore. The bulk of the description and measurements on the whole and split cores was conducted during the Onshore Science Party (OSP) at the IODP Bremen Core Repository (Germany). Table T2 shows which measurements were conducted offshore and which ones at the OSP.

\section{Sedimentology and biological assemblages}

Nine major lithologic types were recovered from fossil reefs on the shelf edge of the GBR. They are defined as follows:

1. Modern seafloor sediment. These deposits contain a mixture of unconsolidated bioclastic sand to pebbles, with preserved invertebrate skeletons, mud with planktonic components, and lithified crusts consisting mainly of coralline algae, encrusting corals, bryozoans, serpulid worm tubes, and encrusting foraminifera. Crusts commonly have reddish to dark brown stains.

2. Coralgal boundstone. These deposits are built (bound) mainly by corals and coralline algae forming well-developed frameworks. Microbialites are a minor component. They contain variable amounts of loose to lithified internal bioclastic sediments.

3. Coralgal/microbialite boundstone. These deposits are built by varying proportions of coral and coralline algae, along with abundant microbialites, forming well-developed frameworks. They contain variable amounts of loose to lithified internal bioclastic sediments.

4. Microbialite boundstone. These deposits are built mainly by microbialites with a range of morphologies/fabrics (e.g., stromatolitic and digitate) and have minor amounts of coral and coralline algae. They contain variable amounts of loose to lithified internal bioclastic sediments.
5. Packstone/grainstone. These deposits are bioclastic, sand-sized $(<2 \mathrm{~mm})$, and grain-supported, with a high degree of lithification, forming packstone in the presence of mud $(>1 \%)$ and grainstone in the absence of mud $(<1 \%)$. Fragments of larger foraminifera, corals, Halimeda, and mollusks are the most common components of skeletal grains.

6. Rudstone. These deposits are bioclastic, $>2 \mathrm{~mm}$ in size, and grain supported with a high degree of lithification and with $>10 \%$ of grains of granule to pebble size. Coral, Halimeda, and mollusks are the most common components of larger clasts.

7. Lime sand. These unconsolidated sediments are composed of sand-sized $(<2 \mathrm{~mm})$ carbonate grains dominated by fragments of larger foraminifera, corals, Halimeda, and mollusks.

8. Lime granules/pebbles. These unconsolidated sediments are composed of $>10 \%$ pebble-sized clasts. The most common components are larger foraminifera, corals, Halimeda, and mollusks.

9. Mud. These unconsolidated sediments are composed of fine-grained, silt- to clay-sized $(<63$ $\mu \mathrm{M})$ carbonate and/or (siliciclastic) grains.

To aid core description, these lithologic types were organized into distinct lithostratigraphic units numbered from the top of each hole (e.g., Units 1 and 2). Note that lithostratigraphic units of the same designation from different holes are not correlative in time. Comprehensive definition of distinct chronostratigraphic units and their correlation between sites will only be possible after detailed analyses of the sedimentary facies and chronology data during postcruise research.

\section{Transect HYD-01C: Holes M0030A-M0039A}

The northern Hydrographer's Passage transect, HYD01C, consists of 11 holes. From landward to seaward, they are Holes M0034A, M0030A and M0030B, M0031A, M0032A, M0033A, M0035A, M0036A, M0038A, M0039A, and M0037A, starting at depths between 51.0 and $122.3 \mathrm{mbsl}$. Several holes are closely spaced (i.e., $<20 \mathrm{~m}$ apart) and could be treated as a composite hole (or site) through distinct reef targets: Site $5=$ Holes M0030A and M0030B in the 80 mbsl reef target, Site $6=$ Holes M0031A, $\mathrm{M} 0032 \mathrm{~A}$, and M0033A in the $90 \mathrm{mbsl}$ reef target, and Site $8=$ Holes M0038A and M0039A in the $110 \mathrm{mbsl}$ reef target. Figure F125 in the "Transect HYD-01C" chapter summarizes the major lithostratigraphic units for transect HYD-01C, including their distribution and recovery. 


\section{Sedimentology and biological assemblages}

Coralgal and coralgal-microbialite boundstones are the dominant lithologies recovered along transect HYD-01C (see Fig. F125 in the "Transect HYD-01C" chapter). Just below the modern seafloor, between one and three coralgal boundstone and coralgal-microbialite boundstone units occur in most transect HYD-01C holes, except for Holes M0030A and $\mathrm{M} 0030 \mathrm{~B}$, in which recovery was extremely low, and Hole M0037A, the most distal and deepest site on the transect (at $122 \mathrm{mbsl}$ ).

The coralgal lithologies, spanning one or two sections depending on the hole, contain little or no microbialite and range from $<1 \mathrm{~m}$ thickness in Hole M0032A to $8 \mathrm{~m}$ in Hole M0031A. These coralgal lithologies consistently overlie coralgal-microbialite units in Holes M0031A-M0033A, M0035A, M0036A, M0038A, and M0039A. In Hole M0034A, a 2 m thick coral boundstone underlies an $18 \mathrm{~m}$ thick coralgalmicrobialite unit, whereas in Hole M0036A, the coralgal boundstone is interbedded with a $6 \mathrm{~m}$ of unconsolidated sediment unit. The main corals in the coralgal units are massive Isopora with lesser amounts of massive Porites, submassive to massive Montipora, and branching Acropora.

The coralgal-microbialite units are dominated volumetrically by microbialites, and these boundstones are the thickest lithologies in every hole except Hole M0037A. They range from $10 \mathrm{~m}$ thick in Hole M0031A to $\sim 30 \mathrm{~m}$ thick in Hole M0033A. They contain diverse coral assemblages dominated by massive Isopora, branching Acropora, and Seriatopora, but also locally abundant massive Porites and Faviidae.

In six of the nine holes along transect HYD-01C, unconsolidated sediment from $<1 \mathrm{~m}$ to $19 \mathrm{~m}$ thick underlies the upper coralgal-microbialite boundstone units and is composed of bioclastic lime sand to pebbles containing mollusks, larger foraminifera, Halimeda, fragments of corals and red algae, bryozoans, echinoderms, and sea urchin spines. In Hole $\mathrm{M} 0034 \mathrm{~A}$, the unconsolidated unit is overlain by a coralgal lithology, whereas in Hole M0036A, the unconsolidated unit is bracketed by coralgal units. These unconsolidated sediments were probably partly disturbed by coring operations.

A thin $(<3 \mathrm{~m})$ skeletal packstone to grainstone unit rich in larger foraminifera, calcareous algae, and/or a dark coralgal-worm tube boundstone is interbedded with, or underlies, the unconsolidated sediment unit in Holes M0031A-M0033A, M0035A, M0036A, M0038A, and M0039A. A similar unconsolidated unit also forms the base of the recovered sequences in Holes M0031A and M0036A.
Hole M0037A, the most distal and deepest site at 122 mbsl along transect HYD-01C, has a different lithologic composition and succession, with almost uninterrupted unconsolidated sediments extending from the seafloor to the base of the hole. The uppermost $12 \mathrm{~m}$ of unconsolidated lime sands to pebbles overlie a thin $(10 \mathrm{~cm})$ interval of grainstone rich in foraminifera, coralline algae, and coral fragments that in turn overlies $8 \mathrm{~m}$ of lime sand rich in larger foraminifera and mollusks. Although there is clear evidence of downhole contamination in the upper part of each section, these deposits appear to be undisturbed and therefore are probably in situ, with minimal disturbance from downhole contamination.

\section{Physical properties}

Partial recovery was achieved in holes drilled on transect HYD-01C. The cores were only partially saturated and often underfilled, thus impacting the data coverage and quality for the physical property measurements. Water depths and borehole depths are as follows:

Hole M0031A = 90.05 mbsl, 43 m drilling depth below seafloor (DSF-A).

Hole M0032A = 91.58 mbsl, 36.70 m DSF-A.

Hole M0033A = 91.30 mbsl, 32.80 m DSF-A.

Hole M0034A = 51 mbsl, 23.10 m DSF-A.

Hole M0035A = 100 mbsl, 29.9 m DSF-A.

Hole M0036A = $103.21 \mathrm{mbsl}, 34 \mathrm{~m}$ DSF-A.

Hole M0037A $=122.29$ mbsl, 21 m DSF-A.

Hole M0039A = 107.04 mbsl, 28.4 m DSF-A.

\section{Density and porosity}

Density and porosity vary similarly in all of the boreholes drilled across transect HYD-01C. Discrete sample porosity ranges from $20 \%$ to $50 \%$ due to significant variability in the pore systems (e.g., moldic, vuggy, growth framework, and intergranular) (see Fig. F126 in the "Transect HYD-01C" chapter). Bulk densities of discrete samples vary between 1.7 and $2.4 \mathrm{~g} / \mathrm{cm}^{3}$. Densities measured on whole cores with the multisensor core logger (MSCL) are $<2 \mathrm{~g} / \mathrm{cm}^{3}$. This is most likely due to the partial saturation of the cores but also a function of the majority of the core comprising unconsolidated fragments. There is a classic linear correlation between the porosity $(\phi)$ and the bulk density ( $\rho$ ) of the discrete samples (see Fig. F127 in the "Transect HYD-01C" chapter):

$$
\rho=\rho_{s}(1-\phi)+\rho_{w} \phi
$$

where

$\rho_{\mathrm{s}}=$ average grain density $\left(\mathrm{g} / \mathrm{cm}^{3}\right)$ and

$\rho_{\mathrm{w}}=$ fluid density $\left(\mathrm{g} / \mathrm{cm}^{3}\right)$. 
This correlation demonstrates that the average grain density along transect HYD-01C is $2.77 \mathrm{~g} / \mathrm{cm}^{3}$. Grain density varies between 2.7 and $2.85 \mathrm{~g} / \mathrm{cm}^{3}$ and may represent a density value between the density of calcite $\left(2.71 \mathrm{~g} / \mathrm{cm}^{3}\right)$ and aragonite $\left(2.93 \mathrm{~g} / \mathrm{cm}^{3}\right)$.

\section{P-wave velocity}

A cross-plot of acoustic velocity ( $P$-wave velocity, $V_{\mathrm{P}}$ ) versus porosity (both from discrete samples) for all sites shows an inverse relationship (see Fig. F128 in the "Transect HYD-01C" chapter). MSCL data, which were acquired cross core (over $\sim 6.5 \mathrm{~cm}$ ), range from 1500.34 to $1937.94 \mathrm{~m} / \mathrm{s}$, much lower values than those obtained from discrete measurements on core plugs. The scale dependency of petrophysical measurements, along with the inevitable difference in "selective" sampling of core as opposed to bulk MSCL measurements is evident: for a given porosity value, discrete measurements have higher $V_{\mathrm{p}}$ values than those obtained from MSCL measurements. On the high end of the range in velocity for a given porosity, these differences can be interpreted as the added effect of pore characteristics, such as pore shape and connectivity, and textural properties of the coralgal and microbialite boundstone units. The differences on the low end of the range in velocity for a given porosity may originate from lack of burial compaction and/or pronounced diagenesis.

\section{Magnetic susceptibility}

MSCL magnetic susceptibility data collected at this transect are difficult to interpret as a result of gaps in the data due to limited core recovery. However, it is clear that the majority of data falls between $-5 \times 10^{-5}$ and $5 \times 10^{-5}$ SI across all the holes with occasional clear magnetic susceptibility highs defined by smooth curves.

\section{Electrical resistivity}

The electrical conductivity of rock depends linearly on the electrical conductivity of the saturating fluid. In the presence of clays, an additional surface conductivity may be added to the previous volume conductivity. The volume conductivity of the rock is sensitive to the microgeometrical properties of the rock, such as porosity and tortuosity. Reliable resistivity measurements were difficult to obtain using the MSCL because of the presence of loose sediments or partially saturated rocks. Low resistivity values were given by unconsolidated or sandy sediments, (e.g., Hole M0037A, 1-2 m CSF, where resistivity is between 1 and $2 \Omega \mathrm{m}$ ). Relatively higher resistivities were found when measuring more consolidated sediments (e.g., Hole M0034A, 12-14 m CSF, where resis- tivity is between 10 and $30 \Omega \mathrm{m}$ [coral framework and microbialite]). A more detailed study of electrical properties of the sediments would require measurements with fully saturated discrete samples.

\section{Color reflectance}

Color reflectance spectrophotometry values were calculated for each of the boreholes as discrete measurements. The main parameters measured are total reflectance $\left(\mathrm{L}^{*}\right)$ and the color indexes $\mathrm{a}^{*}$ (green to red, green being negative and red positive) and $b^{*}$ (blue to yellow, blue being negative and yellow positive). The ratio $\mathrm{a}^{*} / \mathrm{b}^{*}$ was also calculated for all boreholes, as it can be used as a better proxy to identify changes in sediment characteristics than the independent values of $\mathrm{a}^{*}$ and $\mathrm{b}^{*}$.

Measurements were taken in the most uniform color zones in a unit. This is shown by the data in the sense that massive corals sampled in several points present a consistent pattern of color. In these situations, the data obtained show a main value with a small deviation for the three parameters $\left(L^{*}, a^{*}, b^{*}\right)$. In the locations where Tubipora sp. was found, a strong signal in the red spectrum $\left(\mathrm{a}^{*}\right)$ was present. In most of the boreholes, slightly higher values of reflectance occur just below the seafloor where modern reef sediment was recovered.

Along transect HYD-01C, Holes M0031A-M0033A are located in similar water depths and can be correlated. No significant trends were found in these cores, but the reflectance values for these boreholes are similar. This is also true for Holes M0035A and M0036A. Discrete measurements of reflectance values for all boreholes along transect HYD-01C are represented in Figure F129 in the "Transect HYD-01C" chapter. Boreholes are represented in landward to seaward order. All cores are presented in core depth below seafloor in meters (m CSF).

\section{Downhole measurements}

Downhole geophysical logs provide continuous information on physical, chemical, textural, and structural properties of geological formations penetrated by a borehole. In intervals of low or disturbed core recovery, downhole geophysical logs provide the only way to characterize the borehole section. This is especially true when recovery is poor and when comparable measurements or observations cannot be obtained from core, as downhole geophysical logging allows precise depth positioning of core pieces by visual (borehole images) or petrophysical correlation.

The suite of downhole logging tools deployed at transect HYD-01C comprised the following:

- Spectral Natural Gamma Probe (ASGR), 
- Induction Resistivity Probe (DIL 45),

- Full Waveform Sonic Probe (SONIC; 2PSA-1000), and

- Magnetic Susceptibility Probe (EM51).

Wireline logging operations on transect HYD-01C provided two sets of comparable through-pipe gamma ray data. Very few open-hole data were acquired in Hole M0036A because of hole instability. However, it was possible to discern three major logging units at these two sites based on the gamma ray data collected through American Petroleum Institute (API) pipe (see Fig. F130 in the "Transect HYD-01C" chapter):

- The upper unit has elevated values of natural radioactivity and is associated with coralgal boundstone.

- The middle unit yields low values of natural radioactivity and is associated with unconsolidated material (carbonate lime sand and pebbles) in Hole M0031A and a coralgal-microbialite boundstone in Hole M0036A.

- The basal unit has a trend of increasing natural radioactivity toward the bottom of the hole. This manifested as unconsolidated material in Hole M0031A, whereas in Hole M0036A a dark-colored, bioeroded boundstone followed by a packstone comprising benthic foraminifera (no corals) is present. The base of Hole M0036A comprises unconsolidated coarse carbonate lime sand and pebbles.

Both total gamma ray (TGR) curves obtained at Holes M0031A and M0036A had a similar trend; therefore, it was expected that similar formations might be present. However, there are some significant differences in the deposits recovered by the drill holes (see Fig. F130 in the "Transect HYD-01C" chapter). It is not certain whether the large amount of unconsolidated material cored at Hole M0031A is truly representative of the in situ formation or whether the differences between the two holes, which are only $\sim 800 \mathrm{~m}$ apart (Hole M0031A at $\sim 90$ $\mathrm{m}$ water depth and Hole M0036A at $103 \mathrm{~m}$ water depth), are related to low recovery and core quality.

\section{Transect HYD-02A: Sites M0040A-M0048A}

The southern Hydrographer's Passage transect, HYD02A, includes nine holes. From landward to seaward they are Holes M0042A, M0048A, M0047A, M0043A, M0045A, M0046A, M0044A, M0040A, and M0041A, starting at depths between 50.8 and $126.1 \mathrm{mbsl}$. Some holes are closely spaced (i.e., $<5 \mathrm{~m}$ apart) and these can be treated as a composite hole (or site) through the same reef target: Site $8=$ Holes M0045A and M0046A in the 110 mbsl reef target; Site $10=$
Holes M0040A and M0041A in the 120 mbsl reef target. Figure F88 in the "Transect HYD-02A" chapter summarizes the major lithostratigraphic units for transect HYD-02A, including their distribution and recovery.

\section{Sedimentology and biological assemblages}

Few common patterns link lithologic successions in the eight holes along transect HYD-02A (see Fig. F88 in the "Transect HYD-02A" chapter). The following highlights describe some features along transect HYD-02A, focusing on shared features rather than on exceptions.

- In several holes, the upper sedimentary unit consists of unconsolidated to lithified modern or subrecent seafloor sediment that is coarser grained in the shallower holes (M0042A and M0044A) and finer grained in the deeper ones (Holes M0040A and M0041A).

- Coralgal, coral-microbialite, and microbialite boundstones occur immediately below the modern sediments in all eight holes along the transect. Their thickness averages $9-10 \mathrm{~m}$ in the deepest two holes (M0040A and M0041A) and the shallowest hole (M0042A) and increases to $25 \mathrm{~m}$ in the two holes at intermediate depths (Holes M0047A and M0043A).

- In every hole that penetrated below the boundstone, there is a unit of unconsolidated material, usually lime sand, in which Halimeda is one of the main components. Recovered thicknesses of this material ranged from 5 to $10 \mathrm{~m}$.

- The two holes (M0042A and M0043A) that penetrated below the unconsolidated interval encountered a packstone/grainstone unit, $<1 \mathrm{~m}$ thick, that overlies unconsolidated sand in Hole M0043A and overlies alternating intervals of lithified grainstone to rudstone and unconsolidated sands in Hole M0042A. The lithified intervals in Hole M0042A contain clear evidence of subaerial exposure, including calcrete and possible root remains.

The boundstone lithologies contain variable proportions of coral, coralline algae, and microbialite that define several coralgal, coralgal-microbialite, and microbialite boundstones similar to those in the other GBR transects. Major corals in the boundstones are submassive to massive Porites, Montipora, branching Pocilloporidae, branching Acropora, massive Isopora, and submassive to massive Faviidae.

Common patterns of boundstone distribution in most of the holes are as follows:

- Coralgal boundstones, from 4 to $24 \mathrm{~m}$ thick, are the uppermost or only boundstone in six of the 
eight holes (excluding Holes M0040A and M0044A).

- Microbialite-rich boundstones (coralgal-microbialite or microbialite boundstones) lie beneath the coralgal boundstone or are the only boundstone lithology in Holes M0043A and M0042A.

- Microbialite boundstone, 4 to $7 \mathrm{~m}$ thick, occurs only in the deepest two holes (M0040A and M0041A).

The presence/absence of coralgal and coralgal-microbialite boundstones has no simple relationship to the geographic location and/or water depth of holes along transect HYD-02A.

\section{Physical properties}

Recovery for transect HYD-02A sites averaged 21\%. However, recovery in Holes M0040A and M0041A reached $\sim 50 \%$. Cores were partially saturated and often disturbed, fractured, or contaminated, thus affecting the quality of the physical property data. Water depths and borehole depths are as follows:

Hole M0040A = 126.07 mbsl, 21.50 m DSF-A. Hole M0041A $=126.58$ mbsl, $22.10 \mathrm{~m}$ DSF-A. Hole M0042A $=50.78$ mbsl, 46.40 m DSF-A. Hole M0043A = 102.93 mbsl, 35 m DSF-A. Hole M0044A = 105.25 mbsl, 11.00 m DSF-A. Hole M0045A = 105.25 mbsl, 14.60 m DSF-A. Hole M0046A = 117.49 mbsl, 20.40 m DSF-A. Hole M0047A = 99.12 mbsl, 33.20 m DSF-A. Hole M0048A = 104.57 mbsl, 7.10 m DSF-A.

\section{Density and porosity}

Bulk density was measured for transect HYD-02A using the gamma ray attenuation (GRA) sensor on the MSCL, providing an estimate of bulk density from whole cores. Discrete moisture and density measurements were also taken with a pentapycnometer on plugs and/or rock fragments, providing grain density, bulk density (in the case of plug samples), and porosity data. As in the previous transect (HYD01C), a classical linear correlation was observed between the porosity $(\phi)$ and bulk density $(\rho)$ of the discrete samples measured in all boreholes along transect HYD-02A (see Fig. F89 in the "Transect HYD-02A" chapter). This correlation demonstrates that the average grain density along transect HYD02A was $2.77 \mathrm{~g} / \mathrm{cm}^{3}$. Grain density varied between 2.7 and $2.85 \mathrm{~g} / \mathrm{cm}^{3}$ and may correspond to a value between the grain density of calcite $\left(2.71 \mathrm{~g} / \mathrm{cm}^{3}\right)$ and aragonite $\left(2.93 \mathrm{~g} / \mathrm{cm}^{3}\right)$. Porosity values for all boreholes in this transect are shown in Figure F90 in the "Transect HYD-02A" chapter. Similar trends in porosity can be picked out in Holes M0047A and M0043A with a zig-zag step decrease in porosity at
0-12 m CSF-A followed by an increase at $~ 15$ m CSF$\mathrm{A}$ and a gradual decrease to $\sim 25 \mathrm{~m}$ CSF-A. Holes M0040A and M0041A have almost identical trends with $\sim 30 \%$ porosity $(\sim 0-10 \mathrm{~m}$ CSF) increasing to $\sim 50 \%$ toward the bottom of the drill holes.

\section{P-wave velocity}

A cross-plot of $P$-wave velocity versus porosity (both from discrete samples) for all sites show an inverse relationship (see Fig. F91 in the "Transect HYD-02A" chapter). Whole-core MSCL data (across $\sim 6.6 \mathrm{~cm}$ ) ranged from 1509 to $1896 \mathrm{~m} / \mathrm{s}$. As expected, because of the bias toward good quality material in the sampling of cores for discrete measurement compared to the more indiscriminate nature of the MSCL measurement, discrete $P$-wave data is generally higher and more reliable than the corresponding MSCL $P$ wave data.

\section{Magnetic susceptibility}

Offshore MSCL magnetic susceptibility data were difficult to interpret for this transect because of limited core recovery in all holes. Magnetic susceptibility values were generally similar across the holes, with the majority of readings in the $-1 \times 10^{-5}$ to $1 \times 10^{-5} \mathrm{SI}$ range, delineated by short intervals of higher magnetic susceptibility.

\section{Electrical resistivity}

Resistivity is variable over the entire transect, with the lowest values $(0.56 \Omega \mathrm{m})$ measured in Hole M0040A and the highest values $(44.84 \Omega \mathrm{m})$ recorded in Hole M0044A. Because of relatively poor core quality and undersaturated cores, data should be treated with caution.

\section{Color reflectance}

In the HYD-02C transect, Holes M0048A, M0047A, M0043A, M0044A, and M0046A are located in similar water depths and can be correlated (with $<5 \mathrm{~m}$ between the drilled holes). Holes M0047A and M0043A exhibited similar trends, but Hole M0047A presented less scatter in the values of reflectance per section, probably because of the presence of massive corals. Hole M0046A had a trend similar to that in the shallower holes; however, the reflectance measurements had a smoother distribution. Holes M0048A and M0044A had similar values. However, because of the lack of measurements with depth in Hole M0048A, there are no trends to compare. Recovery in Hole M0045A was so low that color reflectance was not measured.

Holes M0040A and M0041A are located very close to each other at the same water depth. Both boreholes 
exhibited less scatter in color reflectance measurements than other boreholes in this transect. Reflectance data from these boreholes show a consistent pattern of $L^{*}$ values of $\sim 50 \%$ in the top $2.5 \mathrm{~m}$ of the hole, a slight increase at 6-8 m CSF-A, and a decrease downhole to $\sim 50 \%$ at $21 \mathrm{~m} \mathrm{CSF-A.} \mathrm{Color} \mathrm{reflectance}$ measurements for all of the boreholes in transect HYD-02C are represented in Figure F92 in the "Transect HYD-02A" chapter; boreholes have been plotted from landward to seaward (left to right) at the same depth scale.

\section{Downhole measurements}

Wireline logging operations were performed at one API hole (M0042A) along transect HYD-02A. The priority imaging tools (acoustic borehole image [ABI40] and optical borehole image [OBI40]) were also run to see if image data could be obtained in an API hole. However, the standard maximum hole diameter for successful image data acquisition is $15 \mathrm{~cm}$, and API holes tend to have a minimum diameter $\sim 20 \mathrm{~cm}$. Unfortunately, the test run of the imaging tools in the API hole proved unsuccessful.

Downhole logging in transect HYD-02A was conducted with the following set of wireline sondes:

- Optical Borehole Televiewer (OBI40);

- Acoustic Borehole Televiewer (ABI40);

- Spectral Natural Gamma Probe (ASGR);

- Induction Resistivity Probe (DIL45);

- Full Waveform Sonic Probe (SONIC; 2PSA-1000);

- Magnetic Susceptibility Probe (EM51); and

- Caliper Probe (CAL; 2PCA-100).

Four main logging units were identified from the downhole data from Hole M0042A:

1. The upper logging unit is characterized by low TGR counts (through-pipe and open hole), high conductivity, and very low magnetic susceptibility. Borehole diameter is extremely large in this logging unit ( $>40 \mathrm{~cm}$ in places), which may be a consequence of the API bottom-hole assembly (BHA) moving and eroding the top of the open hole. Four main lithostratigraphic units are associated with this logging unit; carbonate sand and algal bindstone, coralgal boundstone, coralgal-microbialite boundstone, and unconsolidated sediment (lime granules and pebbles).

2 . The second logging unit is associated with a sequence of grainstone to unconsolidated sediment (lime granules and pebbles) to grainstone with rhodoliths downsection. These lithostratigraphic unit variations reflected the conductivity data, which exhibited some minor fluctua- tions downhole. TGR gave intermediate values, and conductivity did not vary. Magnetic susceptibility was extremely low and constant while the borehole diameter was in gauge.

3. The third logging unit is characterized by a downhole increase in TGR, relatively high conductivity values, and a stable borehole diameter. Lithologies associated with this logging unit are (in downsection order) grainstone with rhodoliths, unconsolidated sediment (lime granules and pebbles), and gray rudstone and rudstone units with brown staining.

4. The bottom logging unit represents a zone of reduced total gamma counts. A decline in conductivity is evident at the top of this unit, followed by a gradual increase to the base of the hole. During logging, magnetic susceptibility remained very low and only fluctuated slightly while the caliper registered the hole to be in gauge. Only one lithology is associated with this logging unit: rudstone with brown staining.

\section{Transect RIB-02C: Sites M0049A-M0051A}

Transect RIB-02C includes (landward to seaward) Holes M0051A, M0050A, M0049A, and M0049B at depths between 78.1 and 97.6 mbsl. Holes M0050A, M0049A, and M0049B are closely spaced $(<5 \mathrm{~m}$ apart) and form a composite hole in the $100 \mathrm{mbsl}$ reef target. Figure F27 in the "Transect RIB-02A" chapter summarizes the major lithologic types and recovery for all holes in transect RIB-02C.

\section{Sedimentology and biological assemblages}

Only a rough summary of the lithostratigraphic distribution pattern can be proposed for transect RIB-02 because of poor recovery in the four holes M0049A, M0049B, M0050A, and M0051A (see Fig. F27 in the "Transect RIB-02A" chapter). A limited lithological succession is proposed for three holes (M0049A, M0049B, and M0050A) in which drilling penetrated below the modern and subrecent seafloor. In Hole M0050A, recovered material probably represents subrecent seafloor sediment mixed with fossil material. The following lithological succession is proposed:

- At the top of two holes (all except Hole M0049B), the uppermost sediment consists of brown-stained fragments of coralgal boundstone in lime sand that is rich in Halimeda. The fragments appear to include both lithified and unconsolidated modern or subrecent seafloor sediment.

- In Holes M0049B and M0050A, coralgal-microbialite boundstones occur below the modern sediment. The recovered unit varies from 8 to $16 \mathrm{~m}$ 
thick. No underlying lithologic information was obtained.

\section{Physical properties}

Recovery for transect RIB-02A sites averaged $\sim 16 \%$. However, recovery in Holes M0049A and M0049B reached $\sim 20 \%$. Cores were partially saturated and often disturbed, fractured, or contaminated. This can affect the quality of physical property data collected. Water depths and borehole depths for this transect are as follows:

Hole M0049A = 97.63 mbsl, 3.50 m DSF-A. Hole M0049B = $97.63 \mathrm{mbsl}$, 15.6 m DSF-A. Hole M0050A = 97.63 mbsl, 10.5 m DSF-A. Hole M0051A = 79.63 mbsl, 2.50 m DSF-A.

\section{Density and porosity}

Bulk density was measured on transect RIB-02A samples using the GRA sensor on the MSCL, providing an estimate of bulk density from whole cores. Discrete moisture and density measurements were also taken with a pentapycnometer on plugs and/or rock fragments, providing grain density, bulk density (in the case of plug samples), and porosity data. A clear linear correlation is observed between porosity $(\phi)$ and bulk density $(\rho)$ of the discrete samples measured in all boreholes along transect RIB-02A (see Fig. F28 in the "Transect RIB-02A" chapter). The average grain density along transect RIB-02A is $2.78 \mathrm{~g} / \mathrm{cm}^{3}$. Grain density varies between 2.75 and $2.79 \mathrm{~g} / \mathrm{cm}^{3}$ and may represent a value between the grain density of calcite $\left(2.71 \mathrm{~g} / \mathrm{cm}^{3}\right)$ and aragonite $\left(2.93 \mathrm{~g} / \mathrm{cm}^{3}\right)$. Porosity values for measured boreholes in this transect are shown in Figure F29 in the "Transect RIB-02A" chapter. Porosity ranges from $17 \%$ to $45 \%$; however, the majority of porosity values are $\sim 30 \%$.

\section{P-wave velocity}

Only two core plugs were collected from this transect, both from Hole M0049B. A cross-plot of acoustic velocity $\left(V_{\mathrm{P}}\right)$ versus porosity (both from discrete samples) for all sites shows primarily an inverse relationship between VP and porosity. Whole-core MSCL data (over $\sim 6.5 \mathrm{~cm}$ ) ranges from 1505 to 1845 $\mathrm{m} / \mathrm{s}$. As expected because of the targeted nature of taking discrete samples, much lower $P$-wave velocity values were recorded by the MSCL (offshore) for coralgal and microbialite boundstone units compared to discrete measurements taken on core plugs during the OSP.

\section{Magnetic susceptibility}

Magnetic susceptibility (MSCL offshore) data are difficult to interpret for this transect because of low core recovery in all holes. Very few values were obtained on whole cores, but data ranges from $-0.64 \times$ $10^{-5} \mathrm{SI}$ (Hole M0049B) to high values of $31.6 \times 10^{-5} \mathrm{SI}$ (Hole M0050A). The most data were collected for Hole M0049B; however, no obvious trends are visible.

\section{Electrical resistivity}

Over the entire transect, resistivity is highly variable, with the lowest values $(0.56 \Omega \mathrm{m})$ measured in Hole M0040A and the highest values $(44.84 \Omega \mathrm{m})$ recorded in Hole M0044A. Because of relatively poor core quality and undersaturated cores, data should be treated with caution.

\section{Color reflectance}

Along transect RIB-02A, recovery for Hole M0051A was very low $(<10 \mathrm{~cm})$, and only one value of color reflectance spectrophotometry was measured. Holes M0049A, M0049B, and M0050A are located at the same water depth and are therefore comparable. Discrete measurements of reflectance values for all boreholes in this transect are represented in Figure F30 in the "Transect RIB-02A" chapter. No trends are observed in these three boreholes, but reflectance values are consistent in all cores where units were recovered at similar depths downhole.

\section{Transect NOG-01B: Sites M0052A-M0058A}

Transect NOG-01B includes (landward to seaward) Holes M0057A, M0056A, M0055A, M0053A, M0052A-M0052C, M0054A and M0054B, and M0058A (fore reef slope) at depths between 42.3 and $167.1 \mathrm{mbsl}$. Closely spaced $(<5 \mathrm{~m}$ apart $)$ holes M0053A and M0052A-M0052C form a composite hole in the -100 mbsl reef target. Figure F155 in the "Transect NOG-01B" chapter summarizes the major lithologic types and their distribution and recovery for all holes along transect NOG-01B.

\section{Sedimentology and biological assemblages}

The uppermost parts of the seven holes in deeper water (Holes M0052A-M0052C, M0053A, M0054A and $\mathrm{M} 0054 \mathrm{~B}$, and M0055A) contain mud and muddy sand (see Fig. F155 in the "Transect NOG-01B" chapter). Coralgal and coralgal-microbial boundstone units occur below the muds in these holes and at the top of the recovered succession in the two holes in shallower water (Holes M0056A and M0057A). The coralgal boundstones reach thicknesses of 4-15 m and are dominated by corals encrusted by coralline algae. The algal crusts often contain vermetid gastropods and the encrusting foraminifer Homotrema rubrum. The coralgal-microbial boundstone units can 
reach thicknesses of $10-16 \mathrm{~m}$ and contain thick crusts (up to several centimeters) of microbialite, in addition to corals and coralline algae. The main corals in these boundstones are diverse assemblages of branching Acropora, Seriatopora, massive Isopora, Porites, Montipora, Faviidae, and Tubipora.

Unconsolidated sands, as well as consolidated grainstone and rudstone units, lie below the two boundstone units in all but the three holes (M0052AM0052C) in which drilling did not penetrate below the boundstone. The grainstones/rudstones are 4 to $13 \mathrm{~m}$ thick and composed of shell and skeletal fragments of coral, coralline algae, Halimeda, mollusks, and benthic foraminifera.

Although no material was recovered from beneath the grainstone/rudstone unit in Hole M0055A, three Holes (M0053A, M0054A, and M0054B) have a lime sand interval below the lower grainstone/rudstone. In these holes, the downcore succession of unconsolidated and/or modern reef sediment, boundstones, grainstones/rudstones, and lime sand resembles the pattern observed along transect HYD-01C.

In contrast, the uppermost grainstone/rudstone units in Holes M0056A and M0057A overlie a long succession that includes boundstone, grainstone/ rudstone, and packstone units. Coralgal boundstones, $12 \mathrm{~m}$ thick, are the dominant lithology in Hole M0057A and include a thin interval of packstones in the lowest boundstone interval. In Hole M0056A, $8 \mathrm{~m}$ of coralgal-microbial boundstone overlies a $13 \mathrm{~m}$ thick succession of grainstones/packstones. No consistent pattern has yet been extracted in the succession of facies in these holes. The major corals observed in the deeper, older boundstones are encrusting submassive to massive Montipora, massive Porites and Faviidae, and occasional Galaxea or Agariciidae.

Three holes (M0055A, M0056A, and M0057A) contain packstone and grainstone lithologies, with calcrete features including brownish staining, undulating dissolution surfaces, and rhizoliths at the top of the uppermost grainstone rudstone unit and as layers separating intervals within the underlying boundstone. Obvious dissolution of constituents, especially originally aragonitic coral particles, has left moldic porosity, neomorphisms, and other dissolution features. These features are interpreted as several phases of emersion and weathering, including paleosol formation, within the recovered deposits.

Hole M0058A is the deepest hole of Expedition 325, beginning at $167 \mathrm{mbsl}$. Its $41.4 \mathrm{~m}$ length consists mainly of unconsolidated green mud with two intercalated units of fine to medium sand and a few grainstone intervals (Fig. F155 in the "Transect
NOG-01B" chapter). The three mud units in Hole M0058A are characterized by a lack of bedding. Small fragments of mollusk shells and small benthic foraminifera are scattered through the mud. Planktonic foraminifera are present only in Sections 325M0058A-1X-2, 1X-7, 1X-8, 1X-11, and 1X-12, and there are occasional fragments of bryozoan colonies and clypeasteroid burrowing echinoids. Cores 325M0058A-11X and 13X have clear signs of bioturbation. The upper sand/grainstone unit is at least $2 \mathrm{~m}$ thick and consists of fine to medium sand with fragments of well-cemented grainstone, mollusks, bryozoa, coralline algae, echinoids, larger foraminifera, and serpulids. The grainstone consists of shells and fragments of calcareous algae, larger foraminifera, and mollusks. The lower sand unit is $\sim 7 \mathrm{~m}$ thick, consists of fine to medium sand, and is less distinct than the upper sand unit.

\section{Physical properties}

Recovery at holes in the NOG-01B transect was much higher than at other transects visited during Expedition 325, with an average recovery of $\sim 40 \%$. Water depths and borehole depths for each hole in this transect are as follows:

Hole M0052A = 97.63 mbsl, 1.40 m DSF-A. Hole M0052B = $97.63 \mathrm{mbsl}, 6.90 \mathrm{~m}$ DSF-A. Hole M0052C = 97.63 mbsl, $8.80 \mathrm{~m}$ DSF-A. Hole M0053A $=97.87$ mbsl, 37.30 m DSF-A. Hole M0054A = 107.23 mbsl, 18.72 m DSF-A. Hole M0054B = 107.23 mbsl, 33.20 m DSF-A. Hole M0055A = 87.33 mbsl, 31.29 m DSF-A. Hole M0056A $=81.22$ mbsl, 41.29 m DSF-A. Hole M0057A $=42.27$ mbsl, $41.78 \mathrm{~m}$ DSF-A. Hole M0058A = 167.14 mbsl, 41.40 m DSF-A.

\section{Density and porosity}

Two bulk density measurements were taken on cores from transect NOG-01B. The first of these is conducted using a nondestructive method, measuring gamma density (a proxy for bulk density) on whole cores on a MSCL. The second bulk density measurement is taken on discrete samples using a pentapycnometer, on which porosity and grain density data are also acquired. Because of the higher levels of recovery and core quality in this transect, more confidence can be placed in the MSCL data than for the other transects. Bulk density values measured on whole cores range from 1 to $2.52 \mathrm{~g} / \mathrm{cm}^{3}$. Bulk densities measured on discrete samples vary between 0.62 and $2.49 \mathrm{~g} / \mathrm{cm}^{3}$. Plug porosity varies between $20 \%$ and 50\% (see Fig. F156 in the "Transect NOG-01B" chapter). These values are to be expected in reefal carbonates, as they are formations known for high 
heterogeneity. Some grain density values are $<2.71$ $\mathrm{g} / \mathrm{cm}^{3}$; which is less than the density of both calcite $\left(2.71 \mathrm{~g} / \mathrm{cm}^{3}\right)$ and aragonite $\left(2.93 \mathrm{~g} / \mathrm{cm}^{3}\right)$. These low values could be due to an anomalous measurement and/or the presence of clay in the plugs. Data across this transect demonstrate a negative linear relationship between porosity and bulk density, with density increasing with decreasing porosity (see Fig. F157 in the "Transect NOG-01B" chapter).

\section{P-wave velocity}

A cross-plot of $P$-wave velocity $\left(V_{\mathrm{P}}\right)$ versus porosity (both from discrete samples) for all sites indicates an inverse relationship (see Fig. F158 in the "Transect NOG-01B" chapter). However, there was a secondary group of data with extremely high porosity and relatively low $P$-wave velocity. This group of data relates to the lime mud units recovered in Hole M0058A, where MSCL data (over $\sim 6.5 \mathrm{~cm}$ crosscore) range from 1502 to $1830 \mathrm{~m} / \mathrm{s}$. The MSCL values and corresponding discrete measurements are in accord for Hole M0058A because of the high recovery $(\sim 82 \%)$ and nature of the core. For all other holes, much lower values were recorded for coralgal and microbialite units compared to discrete measurements on core plugs.

\section{Magnetic susceptibility}

Magnetic susceptibility data obtained from the MSCL offshore for transect NOG-01A can be used with more confidence than at the previous transects. Over this transect, magnetic susceptibility ranges from $-1.64 \times 10^{-5} \mathrm{SI}$ (Hole M0053A) to $38.20 \times 10^{-5} \mathrm{SI}$ (Hole M0056A). Small variations and trends are clearly visible in Hole M0054B between 15 m CSF-A and $22 \mathrm{~m}$ CSF-A, and an almost continuous record is available for Hole M0058A.

\section{Electrical resistivity}

Obtaining reliable resistivity measurements on whole cores was much easier at this transect with improved recovery. Hole M0058A exhibited the most continuous and convincing record obtained with the MSCL during Expedition 325, with the transect having the best resistivity measurements on cores, mainly because of improved recovery and core quality. Over the entire transect, resistivity is highly variable, with the lowest values $(0.33 \Omega \mathrm{m})$ measured in Hole M0058A and the highest values $(38.20 \Omega \mathrm{m})$ recorded in Hole M0056A. Trends in the data are much more visible at this transect, with some small fluctuations in Hole M0055A.

\section{Color reflectance}

Along transect NOG-01B, Holes M0052A-M0052C and M0053A were located in similar water depths and can be correlated. The same applies for Holes M0054A and M0054B. Hole M0058A was located in the fore reef slope area and represents the longest continuous record obtained during Expedition 325. Holes M0052A and M0052B had low recovery, and reflectance measurements exhibited a similar range across both of them. Hole M0052C also had low recovery, and only two measurements of color reflectance were taken for this borehole. Recovery in Hole M0053A was higher $(\sim 33 \%)$, and color reflectance values taken in the first few meters were consistent with other boreholes along transect NOG-01B at the same depth (Holes M0052A-M0052C). Recovery for Hole M0054A was low but related well to values obtained for Hole M0054B, the neighboring borehole. Discrete measurements of reflectance values for all boreholes along transect NOG-01B are represented in Figure F159 in the "Transect NOG-01B" chapter; boreholes are plotted from landward to seaward (left to right) at the same depth scale. Reflectance has consistent trends for holes located at the same water depth.

\section{Downhole measurements}

Wireline logging operations for transect NOG-01B were performed in one HQ hole (M0054B). This provided the only opportunity to run both of the highpriority imaging tools in a "logging" hole. After completion of coring, ASGR logging through-pipe was performed, and then the HQ drill string was pulled and the coring bit exchanged for an open-shoe casing to provide borehole stability in unstable sections and a smooth exit and entry of logging tools. In addition, seawater was pumped into the hole to try and displace the guar gum drilling mud and condition the hole for open-hole logging. With the exception of the ASGR log through-pipe, logging was obtained over a maximum interval of $\sim 8.5 \mathrm{~m}$. Borehole conditions were relatively hostile, and the lower portion of the hole began to infill. In order to record ultra high-resolution geophysical downhole logging data, acquisition was done in the rooster box, which is heave compensated.

The downhole logging tool suite used in transect NOG-01B was as follows:

- Optical Borehole Televiewer (OBI40),

- Acoustic Borehole Televiewer (ABI40),

- Hydrogeological probe (IDRONAUT),

- Spectral Natural Gamma Probe (ASGR), 
- Induction Resistivity Probe (DIL45),

- Full Waveform Sonic Probe (SONIC; 2PSA-1000),

- Magnetic Susceptibility Probe (EM51), and

- Caliper Probe (CAL; 2PCA-100).

Two main logging units were identified in Hole M0054B (see Fig. F164 in the "Transect NOG-01B" chapter):

1. The first logging unit is characterized by relatively high total gamma counts and generally low conductivity, although there is a gradual increase in conductivity toward the base of this unit. Magnetic susceptibility wavers around 0.7 $\mathrm{mSI}$ throughout, and the caliper showed the borehole to be in gauge. Acoustic images provided a virtual hardness visualization, and within this logging unit the large majority of the formation appears "hard." Lithologies identified within this logging unit included coralgal-microbialite boundstone, lime sand (with Halimeda), and rudstone units. Clearly the boundstones provided more stable borehole conditions.

2. The second unit was defined by lower total gamma counts and higher conductivity values compared to the first unit. There was a minor decrease in magnetic susceptibility compared to the first unit. Caliper data indicated hole widening compared to the upper unit. Acoustic images clearly showed a significant change in lithology at a major shallow dipping boundary. Lithologies observed in this logging unit include a dark gray rudstone unit that passed downhole into a lime sand (with large benthic foraminifera) unit.

Lithological changes and logging unit boundaries do not concur perfectly; however, coring and wireline operations used different methods to measure depth. Further work will therefore be needed to more fully integrate the log and core data.

\section{Geochemistry}

Hole M0058A consists of fine to coarse sediments, unlike other holes, and therefore continuous interstitial water (IW) sampling was achieved (see Table T4 in the "Transect NOG-01B" chapter). Several mud-fine sand units are punctuated by two coarsegrained units at 8.7-9.9 and 28.9-31.3 mbsf. Although there was no systematic vertical variation in the $\mathrm{pH}$, alkalinity, chloride, ammonia, and strontium concentrations increased with depth from 0.1 to $2.2 \mathrm{mM}$ and 90 to $451 \mu \mathrm{M}$, respectively. The notable characteristic of IW from Hole M0058A is that two large anomalies occur at the discrete coarsegrained units along the profiles of total iron and manganese concentrations.
To determine the mineral abundances and total organic carbon (TOC) contents of sediments from Hole M0058A, X-ray diffraction (XRD) and carbon-sulfur measurements were conducted in the laboratories of University of Bremen. The percent carbonate measured by XRD fluctuated downcore, ranging between $28 \%$ and $76 \%$. Total inorganic carbon (TIC), calculated as the difference between total carbon (TC) and TOC, had a profile similar to percent carbonate. The percent quartz profile showed opposite trends to that of percent carbonate. The two coarse-grained units contain low TOC content, with an average value of $0.25 \%$, compared to the rest of the core. These data suggest that two coarse-grained units may reflect input from terrestrial sources during their deposition. Further investigations are needed to fully understand the cause of lithologic changes found in Hole M0058A.

\section{All transects}

The following disciplines consider trends across all four transects.

\section{Paleomagnetism}

Materials acquired during Expedition 325 generally yielded a low concentration of ferromagnetic materials, coupled with a strong drilling overprint. Therefore, it was very difficult to obtain an integration and assessment of the paleomagnetic results from Expedition 325 during the OSP. Several peaks were detected across some of the holes. However, the nature of these is uncertain, and any possible correlations need to be further investigated through additional rock magnetic studies. Environmental magnetic studies may help refine the climatic origin of these magnetic susceptibility signals and provide information on the volume, composition, and grain size of the magnetic component.

However, it was observed that magnetic susceptibility for transects NOG-01B and RIB-02A was significantly stronger than for the southern Hydrographer's Passage transects (HYD-01C and HYD-02A); the signal along transect RIB-02A was stronger than that observed along transect NOG-01B. One hypothesis is that this may be linked to proximity to a source of magnetic mineral input into the system, suggesting that such a source may exist in the northernmost GBR.

The majority of results are derived from Holes M0040A, M0041A, and M0058A, which provide longer records because of improved recovery rates. In addition, preliminary results obtained from the paleomagnetic study of a U-channel taken from Sec- 
tion 325-M0041A-12R-1 (transect HYD-02A) were also discussed at the OSP.

The "noisy" natural remnant magnetization (NRM) demagnetization paths are attributed to the relatively low intensity of magnetizations $\left(1.08 \times 10^{-9}\right.$ to $2.19 \times 10^{-7} \mathrm{~A} / \mathrm{m}$ with a mean of $\left.2.02 \times 10^{-8} \mathrm{~A} / \mathrm{m}\right)$. Only a few samples are characterized by high NRMs, and these are associated with layers of high values of magnetic susceptibility. Consistency of the NRM inclinations of the discrete cubes measured can also be correlated to the intensity of magnetization results.

The demagnetization method used was not able to remove the magnetization for all core sections. Other methods, such as thermal demagnetization experiments, could be used to remove the overprinting that may be related to the presence of high-coercivity magnetic minerals such as hematite and goethite and thereby reduce the NRM intensity. However, overprinting cannot be erased with standard alternating-field (AF) demagnetization, and there are still uncertainties regarding how the secondary overprint has been acquired and why some samples did not demagnetize at all whereas others had the potential for demagnetization. The component of any drilling-related overprint that may remain will have a negative effect on both the inclination and declination results. However, samples for which the data analysis suggested no overprinting, or for which much of the drilling overprint had been removed, could be used to conduct further studies, such as paleointensity experiments.

The generally positive and high inclination values obtained for Expedition 325 samples are not expected in the low paleolatitude sampling sites (latitudes between $17^{\circ}$ and $19^{\circ} \mathrm{S}$ ) with the corresponding geomagnetic axial dipole (GAD) values of $\sim 31^{\circ}$ to $-38^{\circ} \mathrm{S}$. One interpretation of the results is that a significant portion of the drilling overprint remains on the majority of the samples studied. Alternatively, there may be a pervasive present-field overprint that was not possible to remove with AF demagnetization experiments.

\section{Geochemistry}

A total of 115 IW samples acquired during Expedition 325 were obtained from transects HYD-01C (16), HYD-02A (20), RIB-02A (2), and NOG-01B (77) (numbers in parenthesis indicate the number of samples obtained from each transect). The majority of the IW samples were collected from the holes drilled into the shelf edge fossil coral reefs. The only exceptions were from Hole M0058A, which is located in the deep fore reef slope at Noggin Pass (transect NOG-01B). Recovered material from Hole M0058A is composed of fine to coarse sediments. Measurements of $\mathrm{pH}$, alkalinity, and ammonium concentrations of all of IW samples were made during the offshore phase of the expedition, whereas concentrations of chloride, bromide, sulfate, and major/minor elements were determined by ion chromatography and inductively coupled plasma-optical emission spectrometry (ICP-OES) during the OSP.

The $\mathrm{pH}$, alkalinity, and ammonium concentrations of IW collected from the holes drilled into the shelf edge fossil coral reefs did not indicate any apparent depth-related, not transect-specific variation because of the scarcity of IW samples at each transect (see Tables T5 in the "Transect HYD-01C" chapter, T4 in the "Transect HYD-02A" chapter, T4 in the "Transect RIB-02A" chapter, and T4 in the "Transect NOG01B" chapter). Concentrations of chloride, bromide, sulfate, and most of the characterized major and trace elements vary within the normal range for marine sediments and did not show significant variation between sites and transects.

\section{Chronology}

During the offshore phase of Expedition 325, 68 samples were subsampled from core catcher materials near the base, middle, and top of each hole for preliminary chronology measurements (20 for U-Th and 48 for radiocarbon). These measurements provided approximate age information for each hole before the OSP, thereby aiding the development of targeted sample requests and sampling strategies. U-Th measurements were performed by multicollector inductively coupled plasma-mass spectrometry at the University of Oxford (United Kingdom) and radiocarbon measurements were made by accelerator mass spectrometry at the Australian National University following sample preparation at the University of Tokyo (Japan). To ensure rapid sample throughput and presentation of data before the OSP, no sample screening for diagenesis or detrital contamination was performed for either U-Th or radiocarbon measurements. Therefore, age interpretations may be inaccurate and will need to be refined by further measurements after the OSP. Of the 33 holes drilled during Expedition 325, 26 had at least one preliminary dating measurement and 18 had at least three measurements. Of the holes that had more than one preliminary dating measurement, the age interpretations in all but one (Hole M0037A) were in stratigraphic order, adding confidence to the age interpretations and the notion that core catcher material is often broadly representative of in situ stratigraphy.

A total of 60 age interpretations were from 30 to 0 cal y BP, with eight older ages interpreted from the 
preliminary data (Fig. F11). The 60 ages from 30 to 0 cal y BP are from core catchers that were drilled from between 130 and 51 mbsl. Preliminary age interpretations therefore demonstrate that Expedition 325 has successfully recovered a complete sequence of material from the LGM through the first half of the last deglaciation up to $10 \mathrm{ka}$. Therefore, the material recovered will enable investigation of the magnitude and nature of sea level change around the LGM, as well as the rise of sea level out of the glacial period. The rise of sea level during the early stages of deglaciation will also be refined with further chronological and paleoenvironmental analysis. Thus, Expedition 325 has recovered material from key periods of interest for sea level change and environmental reconstruction, including Heinrich Events 1 and 2, 19kaMWP, the Bølling-Allerød, MWP1A (and MWP1B), and the YD. The distribution of coral ages recovered during Expedition 325 also fills a gap in the coral record from 16.8 to $14.7 \mathrm{ka}$ (Fig. F11). Paired U-Th and radiocarbon measurements from corals within this gap will be crucial in providing data to refine the radiocarbon calibration, thereby enabling investigation into the carbon cycle during this period of environmental change.

\section{Preliminary scientific assessment}

During the Expedition 325 Onshore Science Party (OSP), emphasis was placed on visual description, measurement of physical properties, and sampling of the cores guided by the preliminary chronology provided by the core catcher samples that were dated by U-Th and ${ }^{14} \mathrm{C}$ prior to the OSP. Thus, the Expedition reports section of the volume contains a robust descriptive and chronologic framework for subsequent postcruise research.

The primary objectives of Expedition 325 require the use of specialized geochemical techniques, paleomagnetic analyses, and detailed investigation of lithological and biological assemblages. These types of analyses were not conducted during the OSP but will be conducted at the institutions of the expedition scientists as part of their postcruise research.

Fulfillment of the Expedition 325 scientific objectives is as follows:

\section{Establish the course of postglacial sea level change in the Great Barrier Reef (i.e., define the exact shape of the deglaciation curve for the period 20-10 cal y BP).}

During the offshore phase, cores were recovered from a succession of fossil reef features from 42 to 127 mbsl. Therefore, most if not all of the postglacial sequence from the LGM to $\sim 10$ cal y BP was recovered. Furthermore, the preliminary chronology provided by the core catcher samples confirmed that the recovered cores span this period. During the OSP, high-quality coral samples, consistent with shallow, high-energy settings, were taken for dating and sea level change investigations, the results of which are expected to fulfill the first objective.

\section{Define sea-surface temperature variations for the region over the period 20-10 cal y BP.}

During the offshore phase, massive coral colonies suitable for paleoclimate studies and spanning the LGM and postglacial sequence were recovered in the cores. During the OSP, $>200$ massive coral colonies, including 17 Porites, were slab-sampled for paleoclimate studies, the results of which are expected to fulfil the second objective.

\section{Analyze the impact of sea level changes on reef growth and geometry.}

During the offshore phase, cores were recovered from holes in various water depths and situated on four transects in three different geographic areas along the GBR. Therefore, results of analyses of samples taken during the OSP will be interpreted in a broad temporal and spatial context, which will allow better understanding of the development of the GRB in response to environmental changes.

\section{Additional scientific outcomes from Expedition 325}

Preliminary dating information and initial observations of the cores at the OSP indicate that several additional scientific outcomes will be achieved:

1. New sea level and paleoclimate information from recovered corals that likely span the LGM (MIS2), pre-LGM (MIS3), and several earlier Pleistocene periods. This will also provide new information about the evolution of the GBR during these periods.

2. A $33.3 \mathrm{~m}$ record of near continuous sedimentation was recovered in Hole M0058A from the fore reef slope. This will provide a high-resolution record of sediment flux from shelf to the slope that will complement the sea level and paleoclimate records derived from the reef cores collecting on the shelf edge.

3. The microbial community structure and function will also be assessed within the Hole M0058 sediments using direct count microscopy and RNA/DNA gene targets. Correlations will be made with offshore and onshore geochemical 
characterizations to describe the subsurface biosphere ecology.

\section{References}

Allison, N., Finch, A.A., Tudhope, A.W., Newville, M., Sutton, S.R., and Ellam, R.M., 2005. Reconstruction of deglacial sea surface temperatures in the tropical Pacific from selective analysis of a fossil coral. Geophys. Res. Lett., 32(17):L17609. doi:10.1029/2005GL023183

Asami, R., Felis, T., Deschamps, P., Hanawa, K., Iryu, Y., Bard, E., Durand, N., and Murayama, M., 2009. Evidence for tropical South Pacific climate change during the Younger Dryas and the Bølling-Allerød from geochemical records of fossil Tahiti corals. Earth Planet. Sci. Lett., 288(1-2):96-107. doi:10.1016/j.epsl.2009.09.011

Bard, E., Hamelin, B., Arnold, M., Montaggioni, L., Cabioch, G., Faure, G., and Rougerie, F., 1996. Deglacial sea-level record from Tahiti corals and the timing of global meltwater discharge. Nature (London, U. K.), 382(6588):241-244. doi:10.1038/382241a0

Bard, E., Hamelin, B., and Delanghe-Sabatier, D., 2010. Deglacial meltwater pulse 1B and Younger Dryas sea levels revisited with boreholes at Tahiti. Science, 327(5970):1235-1237. doi:10.1126/science.1180557

Bard, E., Hamelin, B., Fairbanks, R.G., and Zindler, A., 1990. Calibration of the ${ }^{14} \mathrm{C}$ timescale over the past 30,000 years using mass spectrometric U-Th ages from Barbados corals. Nature (London, U. K.), 345(6274):405410. doi:10.1038/345405a0

Bard, E., Hamelin, B., and Fairbanks, R.G., 1990. U-Th ages obtained by mass spectrometry in corals from Barbados: sea level during the past 130,000 years. Nature (London, U. K.), 346(6283):456-458. doi:10.1038/346456a0

Beaman, R.J., Webster, J.M., and Wust, R.A.J., 2007. New evidence for drowned shelf edge reefs in the Great Barrier Reef, Australia. Mar. Geol., 247(1-2):17-34. doi:10.1016/j.margeo.2007.08.001

Beck, J.W., Récy, J., Taylor, F., Edwards, R.L., and Cabioch, G., 1997. Abrupt changes in early Holocene tropical sea surface temperature derived from coral records. Nature (London, U. K.), 385(6618):705-707. doi:10.1038/ 385705a0

Blanchon, P., and Shaw, J., 1995. Reef drowning during the last deglaciation: evidence for catastrophic sea-level rise and ice-sheet collapse. Geology, 23(1):4-8. doi:10.1130/ 0091-7613(1995)023<0004:RDDTLD>2.3.CO;2

Braga, J.C., and Aguirre, J., 2004. Coralline algae indicate Pleistocene evolution from deep, open platform to outer barrier reef environments in the northern Great Barrier Reef margin. Coral Reefs, 23(4):547-558. doi:10.1007/s00338-004-0414-X

Braithwaite, C.J.R., Dalmasso, H., Gilmour, M.A., Harkness, D.D., Henderson, G.M., Kay, R.L.F., Kroon, D., Montaggioni, L.F., and Wilson, P.A., 2004. The Great Barrier Reef: the chronological record from a new borehole. J. Sediment. Res., 74(2):298-310. doi:10.1306/ 091603740298
Broecker, W.S., 1990. Salinity history of the Northern Atlantic during the last deglaciation. Paleoceanography, 5(4):459-467. doi:10.1029/PA005i004p00459

Broecker, W.S., 1992. Defining the boundaries of the lateglacial isotope episodes. Quat. Res., 38(1):135-138. doi:10.1016/0033-5894(92)90036-I

Brown, J., Collins, M., Tudhope, A.W., and Toniazzo, T., 2008. Modelling mid-Holocene tropical climate and ENSO variability: towards constraining predictions of future change with palaeo-data. Clim. Dyn., 30(1):1936. doi:10.1007/s00382-007-0270-9

Cabioch, G., Banks-Cutler, K.A., Beck, W.J., Burr, G.S., Corrège, T., Edwards, R.L., and Taylor, F.W., 2003. Continuous reef growth during the last $23 \mathrm{cal}$ kyr BP in a tectonically active zone (Vanuatu, southwest Pacific). Quat. Sci. Rev., 22(15-17):1771-1786. doi:10.1016/ S0277-3791(03)00170-7

Camoin, G.F., Colonna, M., Montaggioni, L.F., Casanova, J., Faure, G., and Thomassin, B.A., 1997. Holocene sea level changes and reef development in the southwestern Indian Ocean. Coral Reefs, 16(4):247-259. doi:10.1007/s003380050080

Camoin, G.F., Iryu, Y., McInroy, D.B., and the Expedition 310 Scientists, 2007. Proc. IODP, 310: Washington, DC (Integrated Ocean Drilling Program Management International, Inc.). doi:10.2204/iodp.proc.310.2007

Carter, R.M., and Johnson, D.P., 1986. Sea-level controls on the post-glacial development of the Great Barrier Reef, Queensland. Mar. Geol., 71(1-2):137-164. doi:10.1016/ 0025-3227(86)90036-8

Chappell, J., and Polach, H., 1991. Post-glacial sea-level rise from a coral record at Huon Peninsula, Papua New Guinea. Nature (London, U. K.), 349(6305):147-149. doi:10.1038/349147a0

Clark, P.U., McCabe, A.M., Mix, A.C., and Weaver, A.J., 2004. Rapid rise of sea level 19,000 years ago and its global implications. Science, 304(5674):1141-1144. doi:10.1126/science.1094449

Corrège, T., Gagan, M.K., Beck, J.W., Burr, G.S., Cabioch, G., and Le Cornec, F., 2004. Interdecadal variation in the extent of South Pacific tropical waters during the Younger Dryas event. Nature (London, U. K.), 428(6986):927-929. doi:10.1038/nature02506

Cutler, K.B., Edwards, R.L., Taylor, F.W., Cheng, H., Adkins, J., Gallup, C.D., Cutler, P.M., Burr, G.S., and Bloom, A.L., 2003. Rapid sea-level fall and deep-ocean temperature change since the last interglacial period. Earth Planet. Sci. Lett., 206(3-4):253-271. doi:10.1016/S0012821X(02)01107-X

Davies, P.J., and Peerdeman, F.M., 1998. The origin of the Great Barrier Reef: the impact of Leg 133 drilling. In Camoin, G.F., and Davies, P.J. (Eds.), Reefs and Carbonate Platforms in the Pacific and Indian Oceans. Spec. Publ. Int. Assoc. Sedimentol., 25:23-38.

Davies, P.J., Symonds, P.A., Feary, D.A., and Pigram, C.J., 1989. The evolution of the carbonate platforms of northeast Australia. In Crevello, P.D., Wilson, J.L., Sarg, J.F., and Read, J.F. (Eds.), Controls on Carbonate Platform and Basin Development. Spec. Publ.-Soc. Econ. Paleontol. Mineral., 44:233-258. 
De Deckker, P., and Yokoyama, Y., 2009. Micropalaeontological evidence for late Quaternary sea-level changes in Bonaparte Gulf, Australia. Global Planet. Change, 66(12):85-92. doi:10.1016/j.gloplacha.2008.03.012

DeLong, K.L., Quinn, T.M., Shen, C.-C., and Lin, K., 2010. A snapshot of climate variability at Tathiti at $9.5 \mathrm{ka}$ using a fossil coral from IODP Expedition 310. Geochem., Geophys., Geosyst., 11(6):Q06005. doi:10.1029/ 2009GC002758

Denton, G.H., Anderson, R.F., Toggweiler, J.R., Edwards, R.L., Shaefer, J.M., and Putnam, A.E., 2010. The last glacial termination. Science, 328(5986):1652-1656. doi:10.1126/science.1184119

Deschamps, P., Durand, N., Bard, E., Hamelin, B., Camoin, G., Thomas, A.L., Henderson, G.M., and Yokoyama, Y., submitted. Deglacial melt water Pulse 1A revisited from the new IODP Tahiti record. Nature.

Dubois, N., Kindler, P., Spezzaferri, S., and Coric, S., 2008. The initiation of the southern central Great Barrier Reef: new multiproxy data from Pleistocene distal sediments from the Marion Plateau (NE Australia). Mar. Geol., 250(3-4):223-233. doi:10.1016/j.margeo.2008.01.007

Dullo, W.C., Camoin, G.F., Blomeier, D., Colonna, M., Eisenhauer, A., Faure, G., Casanova, J., and Thomassin, B.A., 1998. Morphology and sediments of the foreslopes of Mayotte, Comoro Islands: direct observations from a submersible. In Camoin, G.F., and Davies, P.J., Reefs and Carbonate Platforms in the Pacific and Indian Oceans. Spec. Publ. Int. Assoc. Sedimentol., 25:219-236.

Edwards, R.L., Beck, J.W., Burr, G.S., Donahue, D.J., Chappell, J.M.A., Bloom, A.L., Druffel, E.R.M., and Taylor, F.W., 1993. A large drop in atmospheric ${ }^{14} \mathrm{C} /{ }^{12} \mathrm{C}$ and reduced melting in the Younger Dryas, documented with ${ }^{230}$ Th ages of coral. Science, 260(5110):962-968. doi:10.1126/science.260.5110.962

Fairbanks, R.G., 1989. A 17,000-year glacio-eustatic sea level record: influence of glacial melting rates on the Younger Dryas event and deep-ocean circulation. Nature (London, U. K.), 342(6250):637-642. doi:10.1038/ $342637 \mathrm{a} 0$

Feary, D.A., Symonds, P.A., Davies, P.J., Pigram, C.J., and Jarrard, R.D., 1993. Geometry of Pleistocene facies on the Great Barrier Reef outer shelf and upper slope-seismic stratigraphy of Sites 819, 820, and 821. In McKenzie, J.A., Davies, P.J., Palmer-Julson, A., et al., Proc. ODP, Sci. Results, 133: College Station, TX (Ocean Drilling Program), 327-351. doi:10.2973/ odp.proc.sr.133.250.1993

Fujita, K., Omori, A., Yokoyama, Y., Sakai, S., and Iryu, Y., 2010. Sea-level rise during Termination II inferred from large benthic foraminifers: IODP Expedition 310, Tahiti Sea Level. Mar. Geol., 271(1-2):149-155. doi:10.1016/ j.margeo.2010.01.019

Gagan, M.K., Ayliffe, L.K., Beck, J.W., Cole, J.E., Druffel, E.R.M., Dunbar, R.B., and Schrag, D.P., 2000. New views of tropical paleoclimates from corals. Quat. Sci. Rev., 19(1-5):45-64. doi:10.1016/S0277-3791(99)00054-2

Gagan, M.K., Ayliffe, L.K., Hopley, D., Cali, J.A., Mortimer, G.E., Chappell, J., McCulloch, M.T., and Head, M.J., 1998. Temperature and surface-ocean water balance of the mid-Holocene tropical western Pacific. Science, 279(5353):1014-1018. doi:10.1126/sci-

ence.279.5353.1014

Gagan, M.K., Hendy, E.J., Haberle, S.G., and Hantoro, W.S., 2004. Post-glacial evolution of the Indo-Pacific Warm Pool and El Niño-Southern Oscillation. Quat. Int., 118119:127-143. doi:10.1016/S1040-6182(03)00134-4

Grammer, G.M., and Ginsburg, R.N., 1992. Highstand versus lowstand deposition on carbonate platform margins: insight from Quaternary foreslopes in the Bahamas. Mar. Geol., 103(1-3):125-136. doi:10.1016/ 0025-3227(92)90012-7

Griffiths, M.L., Drysdale, R.N., Gagan, M.K., Zhao, J.-X., Ayliffe, L.K., Hellstrom, J.C., Hantoro, W.S., Frisia, S., Feng, Y.-X., Cartwright, I., St. Pierre, E., Fischer, M.J., and Suwargadi, B.W., 2009. Increasing Australian-Indonesian monsoon rainfall linked to early Holocene sealevel rise. Nat. Geosci., 2(9):636-639. doi:10.1038/ ngeo605

Griffiths, M.L., Drysdale, R.N., Vohnof, H.B., Gagan, M.K., Zhao, J.-X., Ayliffe, L.K., Hantoro, W.S., Hellstrom, J.C., Cartwright, I., Frisia, S., and Suwargadi, B.W., 2010. Younger Dryas-Holocene temperature and rainfall history of southern Indonesia from $\delta^{18} \mathrm{O}$ in speleothem calcite and fluid inclusions. Earth Planet. Sci. Lett., 295(12):30-36. doi:10.1016/j.epsl.2010.03.018

Guilderson, T.P., Fairbanks, R.G., and Rubenstone, J.L., 1994. Tropical temperature variations since 20,000 years ago: modulating interhemispheric climate change. Science, 263(5147):663-665. doi:10.1126/science.263.5147.663

Hanebuth, T., Stattegger, K., and Grootes, P.M., 2000. Rapid flooding of the Sunda Shelf: a late-glacial sea-level record. Science, 288(5468):1033-1035. doi:10.1126/science.288.5468.1033

Hanebuth, T.J.J., Stattegger, K., and Bojanowski, A. 2009. Termination of the Last Glacial Maximum sea-level lowstand: the Sunda-Shelf data revisited. Global Planet. Change, 66(1-2):76-84. doi:10.1016/j.gloplacha.2008.03.011

Harris, P.T., and Davies, P.J., Submerged reefs and terraces on the shelf edge of the Great Barrier Reef, Australia. Coral Reefs, 8(2):87-98. doi:10.1007/BF00301807

Hopley, D., 2006. Coral reef growth on the shelf margin of the Great Barrier Reef with special reference to the Pompey Complex. J. Coastal Res., 22(1):150-158. doi:10.2112/05A-0012.1

Inoue, M., Yokoyama, Y., Harada, M., Suzuki, A., Kawahata, H., Matsuzaki, H., and Iryu, Y., 2010. Trace element variations in fossil corals from Tahiti collected by IODP Expedition 310: reconstruction of marine environments during the last deglaciation (15 to $9 \mathrm{ka}$ ). Mar. Geol., 271(3-4):303-306. doi:10.1016/j.margeo.2010.02.016

International Consortium for Great Barrier Reef Drilling, 2001. New constraints on the origin of the Australian Great Barrier Reef: results from an international project of deep coring. Geology, 29(6):483-486. doi:10.1130/ 0091-7613(2001)029<0483:NCOTOO>2.0.CO;2

Lambeck, K., 1993. Glacial rebound and sea-level change: an example of a relationship between mantle and sur- 
face processes. In Wortel, M.J.R., Hansen, U., and Sabadini, R. (Eds.), Relationships Between Mantle Processes and Geologic Processes at or near the Earth's Surface. Tectonophysics, 223(1-2):15-37. doi:10.1016/00401951(93)90155-D

Lambeck, K., Purcell, A., Funder, S., Kjær, K., Larsen, E., and Moller, P., 2006. Constraints on the late Saalian to early middle Weichselian ice sheet of Eurasia from field data and rebound modelling. Boreas, 35(3):539-575. doi:10.1080/03009480600781875

Lambeck, K., Purcell, A., Johnston, P., Nakada, M., and Yokoyama, Y., 2003. Water-load definition in the glaciohydro-isostatic sea level equation. Quat. Sci. Rev., 22(24):309-318. doi:10.1016/S0277-3791(02)00142-7

Lambeck, K., Yokoyama, Y., and Purcell, T., 2002. Into and out of the Last Glacial Maximum: sea-level change during oxygen isotope Stages 3 and 2. Quat. Sci. Rev., 21(13):343-360. doi:10.1016/S0277-3791(01)00071-3

Larcombe, P., Carter, R.M., Dye, J., Gagan, M.K., and Johnson, D.P., 1995. New evidence for episodic post-glacial sea-level rise, central Great Barrier Reef, Australia. Mar. Geol., 127(1-4):1-44. doi:10.1016/00253227(95)00059-8

Lindstrom, D.R., and MacAyeal, D.R., 1993. Death of an ice sheet. Nature (London, U. K.), 365(6443):214-215. doi: $10.1038 / 365214 \mathrm{a} 0$

Linsley, B.K., Rosenthal, Y., and Oppo, D.W., 2010. Holocene evolution of the Indonesian throughflow and the western Pacific warm pool. Nat. Geosci., 3(8):578-583. doi:10.1038/ngeo920

Liu, Z., Kutzbach, J., and Wu, L., 2000. Modeling climate shift of El Niño variability in the Holocene. Geophys. Res. Lett., 27(15):2265-2268. doi:10.1029/ 2000GL011452

Locker, S.D., Hine, A.C., Tedesco, L.P., and Shinn, E.A., 1996. Magnitude and timing of episodic sea-level rise during the last deglaciation. Geology, 24(9):827-830. doi:10.1130/0091-

7613(1996)024<0827:MATOES>2.3.CO;2

Macintyre, I.G., Rützler, K., Norris, J.N., Smith, K.P., Cairns, S.D., Bucher, K.E., and Steneck, R.S., 1991. An early Holocene reef in the western Atlantic: submersible investigations of a deep relict reef off the west coast of Barbados, W.I. Coral Reefs, 10(3):167-174. doi:10.1007/ BF00572177

MARGO Project Members, 2009. Constraints on the magnitude and patterns of ocean cooling at the Last Glacial Maximum. Nat. Geosci., 2(2):127-132. doi:10.1038/ ngeo411

Martin, P.A., Lea, D.W., Mashiotta, T.A., Papenfuss, T., and Sarnthein, M., 1999. Variation of foraminiferal Sr/Ca over Quaternary glacial-interglacial cycles: evidence for changes in mean ocean Sr/Ca? Geochem., Geophys., Geosyst., 1(12):1004-1023. doi:10.1029/1999GC000006

McCulloch, M., Mortimer, G., Esat, T., Xianhua, L., Pillans, B., and Chappell, J., 1996. High resolution windows into early Holocene climate: Sr/Ca coral records from the Huon Peninsula. Earth Planet. Sci. Lett., 138(14):169-178. doi:10.1016/0012-821X(95)00230-A
McGregor, H.V. and Gagan, M.K., 2004. Western Pacific coral $\delta^{18} \mathrm{O}$ records of anomalous Holocene variability in the El Niño-Southern Oscillation. Geophys. Res. Lett., 31(11):L11204. doi:10.1029/2004GL019972

McKenzie, J.A., Davies, P.J., Palmer-Julson, A., et al., 1993. Proc. ODP, Sci. Results, 133: College Station, TX (Ocean Drilling Program). doi:10.2973/odp.proc.sr.133.1993

Milne, G.A., Gehrels, W.R., Hughes, C.W., and Tamisiea, M.E., 2009. Identifying the causes of sea-level change. Nat. Geosci., 2(7):471-478. doi:10.1038/ngeo544

Mix, A.C., Bard, E., and Schneider, R., 2001. Environmental processes of the ice age: land, oceans, glaciers (EPILOG). Quat. Sci. Rev., 20(4):627-657. doi:10.1016/ S0277-3791(00)00145-1

Moy, C.M., Seltzer, G.O., Rodbell, D.T., and Anderson, D.M., 2002. Variability of El Niño/southern oscillation activity at millennial timescales during the Holocene epoch. Nature (London, U. K.), 420(6912):162-165. doi:10.1038/nature01194

Nakada, M., 1986. Holocene sea levels in oceanic islands: implications for the rheological structure of the Earth's mantle. Tectonophysics, 121(2-4):263-276. doi:10.1016/ 0040-1951(86)90047-8

Nakada, M., and Lambeck, K., 1987. Glacial rebound and relative sea-level variations: a new appraisal. Geophys. J. R. Astron. Soc., 90(1):171-224.

Oppo, D.W., Rosenthal, Y., and Linsley, B.K., 2009. 2000year-long temperature and hydrology reconstructions from the Indo-Pacific Warm Pool. Nature (London, U. K.), 460(7259):1113-1116. doi:10.1038/nature08233

Otto-Bleisner, B.L., Brady, E.C., Shin, S.-I., Liu, Z., and Shields, C., 2003. Modeling El Niño and its tropical teleconnections during the last glacial-interglacial cycle. Geophys. Res. Lett., 30(23):2198-2201. doi:10.1029/ 2003GL018553

Otto-Bleisner, B.L., Schneider, R., Brady, E.C., Kucera, M., Abe-Ouchi, A., Bard, E., Braconnot, P., Crucifix, M., Hewitt, C.D., Kageyama, M., Marti, O., Paul, A., RosellMelé, A., Waelbroeck, C., Weber, S.L., Weinelt, M., and Yu, Y., 2009. A comparison of PMIP2 model simulations and the MARGO proxy reconstruction for tropical sea surface temperatures at Last Glacial Maximum. Clim. Dyn., 32(6):799-815. doi:10.1007/s00382-008-0509-0

Peltier, W.R., 1994. Ice age paleotopography. Science, 265(5169):195-201. doi:10.1126/science.265.5169.195

Peltier, W.R., and Fairbanks, R.G., 2006. Global glacial ice volume and Last Glacial Maximum duration from an extended Barbados sea level record. In Rose, J., Tzedakis, C., and Elderfield, H. (Eds.), Critical Quaternary Stratigraphy. Quat. Sci. Rev., 25(23-24):3322-3337. doi:10.1016/j.quascirev.2006.04.010

Rodbell, D.T., Seltzer, G.O., Anderson, D.M., Abbott, M.B., Enfield, D.B., and Newman J.H., 1999. An 15,000-year record of El Niño-driven alluviation in southwestern Ecuador. Science, 283(5401):516-520. doi:10.1126/science.283.5401.516

Sandweiss, D.H., Richardson, J.B., III, Reitz, E.J., Rollins, H.B., and Maasch, K.A., 1996. Geoarchaeological evidence from Peru for a 5000 years B.P. onset of El Niño. 
Science, 273(5281):1531-1533. doi:10.1126/science.273.5281.1531

Stocker, T.F., and Wright, D.G., 1991. Rapid transitions of the ocean's deep circulation induced by changes in surface water fluxes. Nature (London, U. K.), 351(6329):729732. doi: $10.1038 / 351729 \mathrm{a} 0$

Stoll, H.M., and Schrag, D.P., 1998. Effects of Quaternary sea level cycles on strontium in seawater. Geochim. Cosmochim. Acta, 62(7):1107-1118. doi:10.1016/S00167037(98)00042-8

Stott, L., Cannariato, K., Thunell, R., Haug, G.H., Koutavas, A., and Lund, S., 2004. Decline of surface temperature and salinity in the western tropical Pacific Ocean in the Holocene epoch. Nature (London, U. K.), 431(7004):5659. doi:10.1038/nature02903

Stuiver, M., and Grootes, P.M., 2000. GISP2 oxygen isotope ratios. Quat. Res., 53(3):277-284. doi:10.1006/ qres.2000.2127

Thomas, A.L., Henderson, G.M., Deschamps, P., Yokoyama, Y., Mason, A.J., Bard, E., Hamelin, B., Durand, N., and Camoin, G., 2009. Penultimate deglacial sea-level timing from Uranium/Thorium dating of Tahitian corals. Science, 324(5931):1186-1189. doi:10.1126/science.1168754

Tudhope, A.W., Chilcott, C.P., McCulloch, M.T., Cook, E.R., Chappell, J., Ellan, R.M., Lea, D.W., Lough, J.M., and Shimmield, G.B., 2001. Variability in the El NiñoSouthern Oscillation through a glacial-interglacial cycle. Science, 291(5508):1511-1517. doi:10.1126/science. 1057969

Wang, Y.J., Cheng, H., Edwards, R.L., An, Z.S., Wu, J.Y., Shen, C.-C., and Dorale, J.A., 2001. A high-resolution absolute-dated late Pleistocene monsoon record from Hulu Cave, China. Science, 294(5580):2345-2348. doi:10.1126/science.1064618

Webster, J.M., Beaman, R.J., Bridge, T., Davies, P.J., Byrne, M., Williams, S., Manning, P., Pizarro, O., Thornborough, K., Woolsey, E., Thomas, A., and Tudhope, S., 2008a. From corals to canyons: the Great Barrier Reef margin. Eos, Trans. Am. Geophys. Union, 89(24):217-218. doi:10.1029/2008EO240002

Webster, J.M., Davies, P., Beaman, R., Williams, S., and Byrne, M., 2008b. Evolution of drowned shelf edge reefs in the GBR; implications for understanding abrupt climate change, coral reef response and modern deep water benthic habitats. Marine National Facility $R V$ Southern Surveyor 2007 Program: Voyage Summary SS07/ 2007: Victoria, Australia (CSIRO). http:// www.marine.csiro.au/nationalfacility/voyagedocs/ 2007/summarySS07-2007.pdf

Webster, J.M., Clague, D.A., Riker-Coleman, K., Gallup, C., Braga, J.C., Potts, D., Moore, J.G., Winterer, E.L., and Paull, C.K., 2004. Drowning of the $-150 \mathrm{~m}$ reef off Hawaii: a casualty of global meltwater pulse 1A? Geology, 32(3):249-252. doi:10.1130/G20170.1
Webster, J.M., and Davies, P.J., 2003. Coral variation in two deep drill cores: significance for the Pleistocene development of the Great Barrier Reef. In Blanchon, P., and Montaggioni, L. (Eds.), Late Quaternary Reef Development. Sediment. Geol., 159(1-2):61-80. doi:10.1016/ S0037-0738(03)00095-2

Wolanski, E., 1982. Aspects of physical oceanography of the Great Barrier Reef lagoon. Proc. Int. Coral Reef Symp., 8:375-381.

Yokoyama, Y., Esat, T.M., and Lambeck, K., 2001a. Coupled climate and sea-level changes deduced from Huon Peninsula coral terraces of the last ice age. Earth Planet. Sci. Lett., 193(3-4):579-587. doi:10.1016/ S0012-821X(01)00515-5

Yokoyama, Y., Esat, T.M., and Lambeck, K., 2001b. Last glacial sea-level change deduced from uplifted coral terraces of Huon Peninsula, Papua New Guinea. Quat. Int., 83-85:275-283. doi:10.1016/S1040-6182(01)00045-3

Yokoyama, Y., Lambeck, K., De Deckker, P., Johnston, P., and Fifield, L.K., 2000. Timing of the Last Glacial Maximum from observed sea level minima. Nature (London, U. K.), 406(6797):713-716. doi:10.1038/35021035

Yokoyama, Y., Nakada, M., Maeda, Y., Nagaoka, S., Okuno, J., Matsumoto, E., Matsushima, Y., and Sato, H., 1996. Holocene sea-level change and hydro-isostasy along the west coast of Kyushu, Japan. Palaeogeogr., Palaeoclimatol., Palaeoecol., 123(1-4):29-47. doi:10.1016/00310182(95)00112-3

Yokoyama, Y., Naruse, T., Ogawa, N.O., Tada, R., Kitazato, H., and Ohkouchi, N., 2006a. Dust influx reconstruction during the last 26,000 years inferred from a sedimentary leaf wax record from the Japan Sea. Global Planet. Change, 54(3-4):239-250. doi:10.1016/j.gloplacha.2006.06.022

Yokoyama, Y., Purcell, A., Lambeck, K., and Johnston, P., 2001c. Shore-line reconstruction around Australia during the Last Glacial Maximum and Late Glacial Stage. Quat. Int., 83-85:9-18. doi:10.1016/S10406182(01)00028-3

Yokoyama, Y., Purcell, A., Marshall, J.F., and Lambeck, K., 2006b. Sea-level during the early deglaciation period in the Great Barrier Reef, Australia. Global Planet. Change, 53(1-2):147-153. doi:10.1016/j.gloplacha.2006.01.014

Yuan, D., Cheng, H., Edwards, R.L., Dykoski, C.A., Kelly, M.J., Zhang, M., Qing, J., Lin, Y., Wang, Y., Wu, J., Dorale, J.A., An, Z., and Cai, Y., 2004. Timing, duration, and transitions of the last interglacial Asian monsoon. Science, 304(5670):575-578. doi:10.1126/science. 1091220

Publication: 16 July 2011 MS 325-101 
Figure F1. A. Previously published data on relative sea level from $20 \mathrm{cal}$ y BP through present (upper symbols) plotted with GISP2 $\delta^{18} \mathrm{O}$ (proxy for temperature over Greenland; black line). Meltwater pulse 1A (MWP-1A) refers to an interval of particularly rapid sea level rise during the last deglaciation. MWP-1B = meltwater pulse 1B, LGM = last glacial maximum, B/A = Bølling-Allerød, and YD = Younger Dryas. Source of data: Tahiti = Bard et al. (1996, 2010); Huon Peninsula = Chappell and Polach (1991), Edwards et al. (1993); Huon drill core = Cutler et al. (2003); Sunda shelf = Hanebuth et al. (2000); Barbados = Fairbanks (1989), Bard et al. (1990); GISP2 $=$ Stuiver and Grootes (2000). B. Planktonic foraminiferal Mg/Ca records of sea-surface temperature (SST) in the western sector of the Western Pacific Warm Pool (WPWP). Comparison of Indonesian and WPWP Globigerinoides ruber $\mathrm{Mg} / \mathrm{Ca}$-based SST anomaly records modified from Linsley et al. (2010). Anomalies calculated as departures relative to average of last $2000 \mathrm{y}$. Data shown are $200 \mathrm{y}$ nonoverlapping binned averages of eight cores throughout the western sector of the WPWP (black) and averages of only four southern Makassar region cores (green). Orange SST data are from Oppo et al. (2009) for only the southern Makassar Strait. Light green and dashed bounding lines show the standard error (SE) of all measurements in each $200 \mathrm{y}$ bin. The LGM, Holocene Climatic Optimum, and Medieval Warm Period (MWP) are indicated. Composite reconstruction indicates that SSTs in this broad region of the WPWP warmed $\sim 3^{\circ} \mathrm{C}$ after the LGM and reached a maximum $0.5^{\circ} \mathrm{C}$ higher than in preindustrial times from $\sim 10,000$ to 7,000 cal y BP during the Holocene Climatic Optimum. (Figure shown on next page.) 
Figure F1 (continued.) (Caption shown on previous page.)
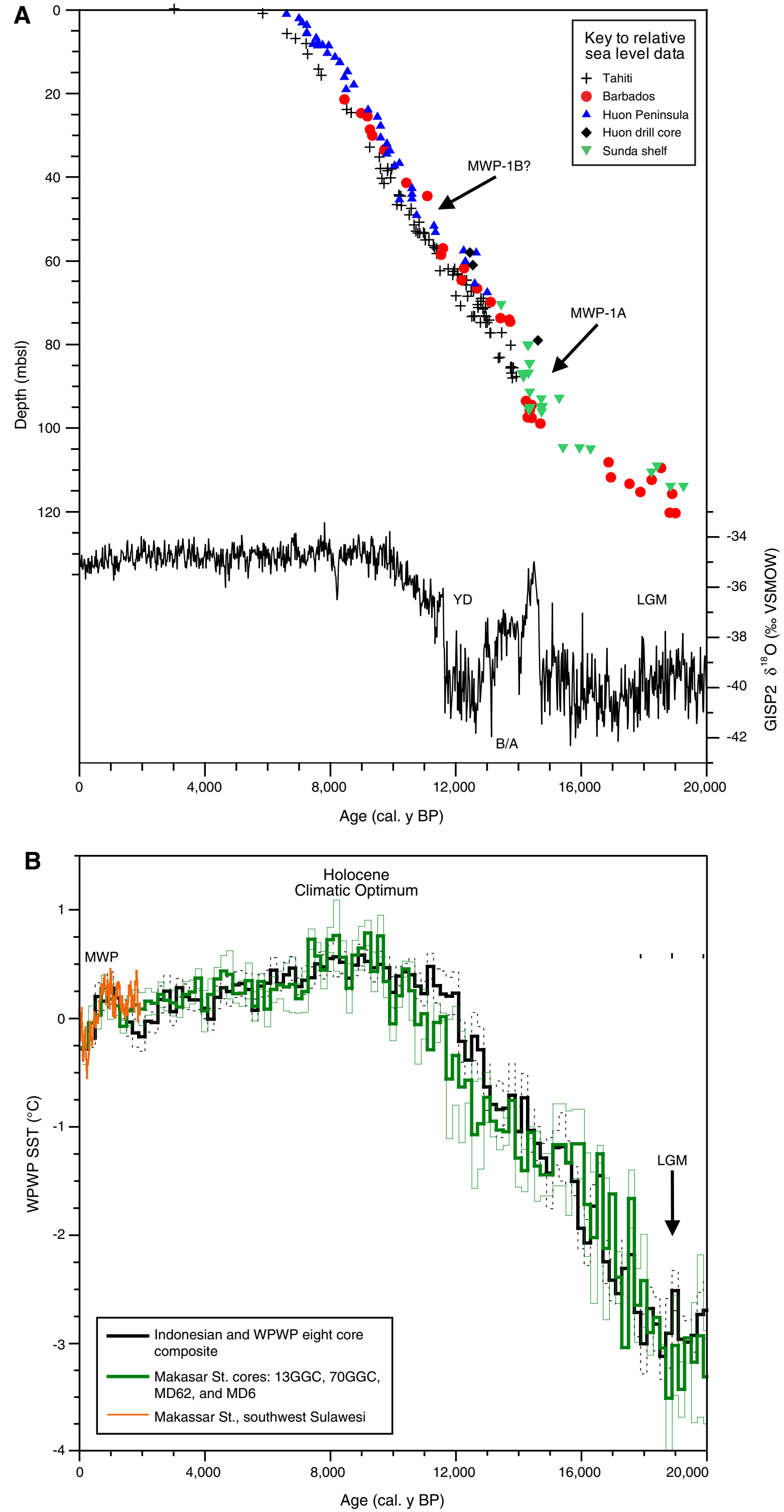
Figure F2. Regional map showing locations of the five proposed drill sites at the following regions: Ribbon Reef 3 and 5 (RIB-02A and RIB-01C, respectively), Noggin Pass (NOG-01B), and Hydrographer's Passage (HYD-01C and HYD-02A). During the offshore phase, Expedition 325 drilled sites at HYD-01C, HYD-02A, NOG-01B, and RIB-02A.

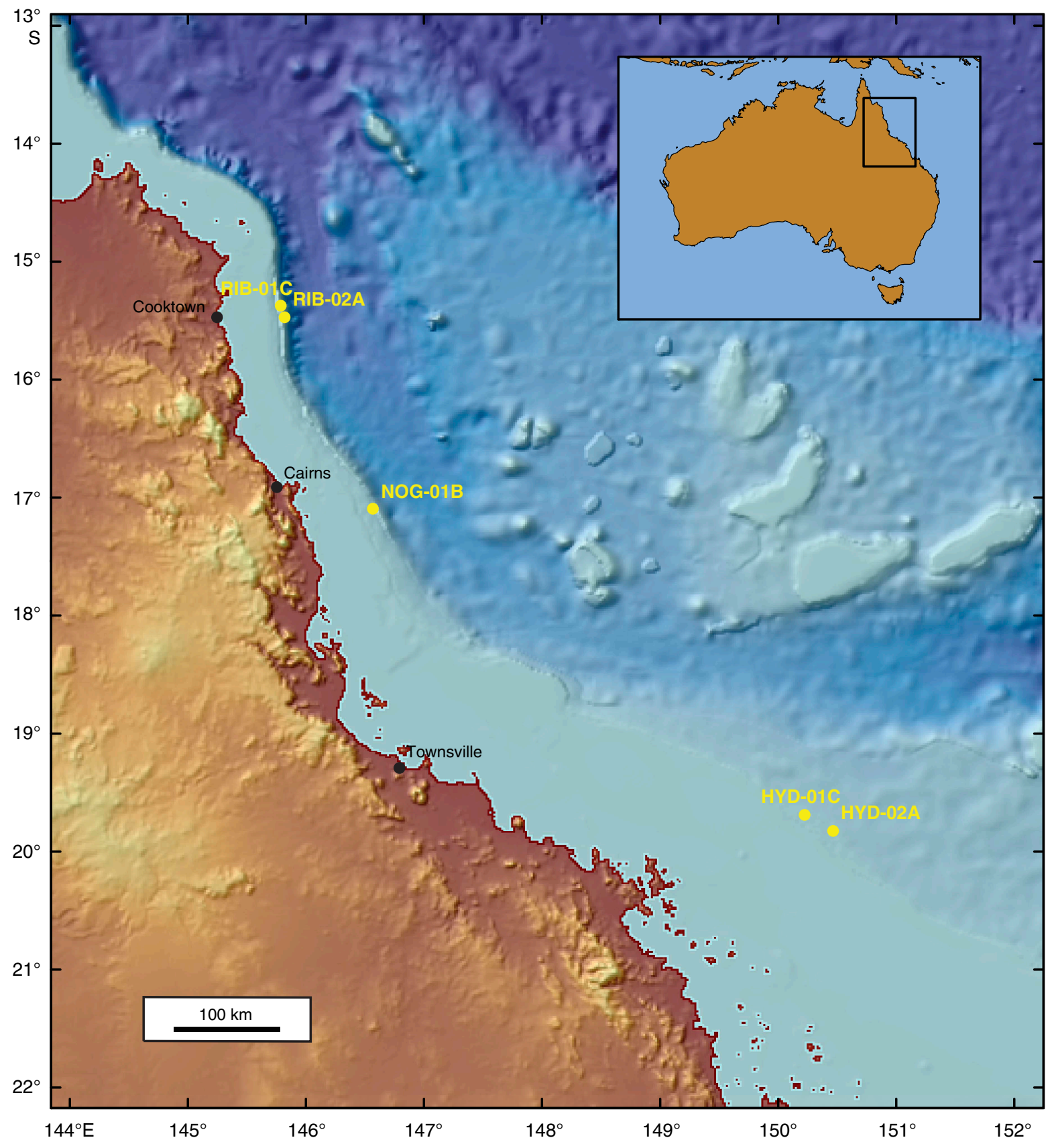


Figure F3. Topas PS18 seismic Profile SEG_SS072007_026_006 showing location of proposed drill sites at transect HYD-01C, Expedition 325. Approximate location of seismic profile is shown in Figure F1 in the "Transect HYD-01C" chapter (proposed transect). Red lines = actual drill locations, solid lines $=$ holes drilled on the seismic profile transect, dashed lines $=$ holes drilled off the seismic profile transect.




Figure F4. Enlargement of Figure F1 in the "Transect HYD-01C" chapter showing holes along transect HYD01C, Expedition 325. A. Holes M0030A-M0033A. B. Holes M0035A-M0039A. EPSP = Environmental Protection and Safety Panel, GBRMPA = Great Barrier Reef Marine Park Authority.

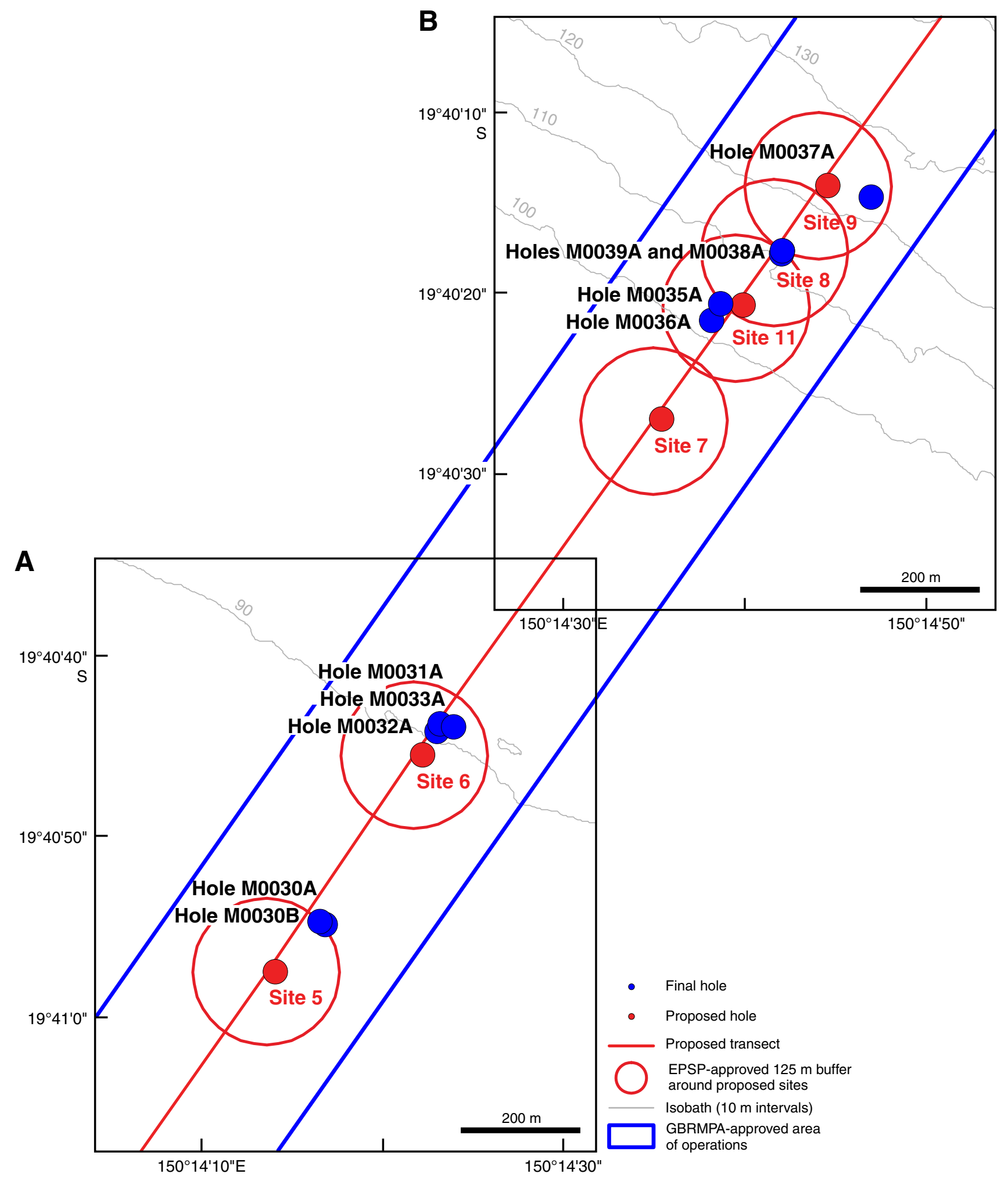


Figure F5. Topas PS18 seismic Profile SEG_SS072007_024_030 showing location of proposed drill sites at transect HYD-02A, Expedition 325. Approximate location of seismic profile is shown in Figure F1 in the "Transect HYD-02A" chapter (proposed transect). Red lines = actual drill locations, solid lines $=$ holes drilled on the seismic profile transect, dashed lines $=$ holes drilled off the seismic profile transect.

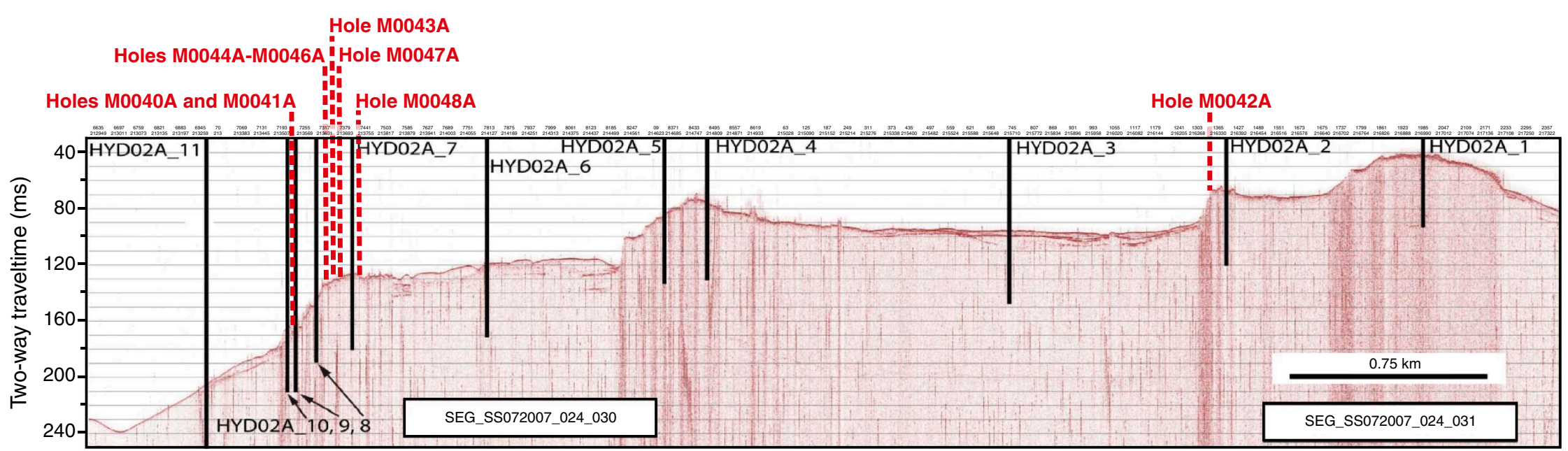


Figure F6. Enlargement of Figure F1 in the "Transect HYD-02A" chapter showing Holes M0040A, M0041A, and M0043A-M0048A at transect HYD-02A, Expedition 325. EPSP = Environmental Protection and Safety Panel, GBRMPA = Great Barrier Reef Marine Park Authority.

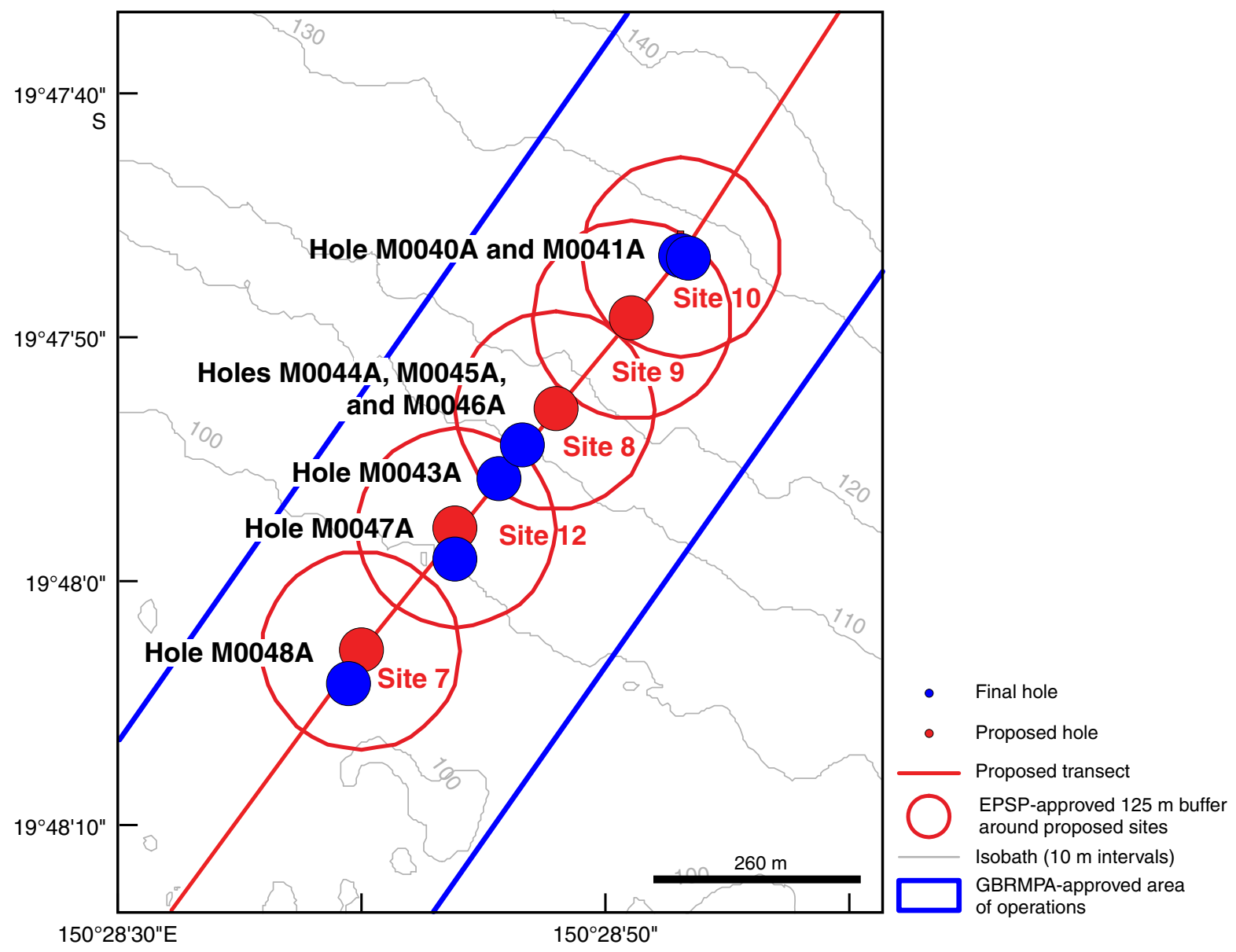


Figure F7. Topas PS18 seismic profile SEG_SS072007_006_003 showing location of proposed drill sites at transect RIB-02A, Expedition 325. Approximate location of seismic profile is shown in Figure F1 in the "Transect RIB-02A chapter" (proposed transect). Red lines = actual drill locations, solid lines = holes drilled on the seismic profile transect, dashed lines $=$ holes drilled off the seismic profile transect.

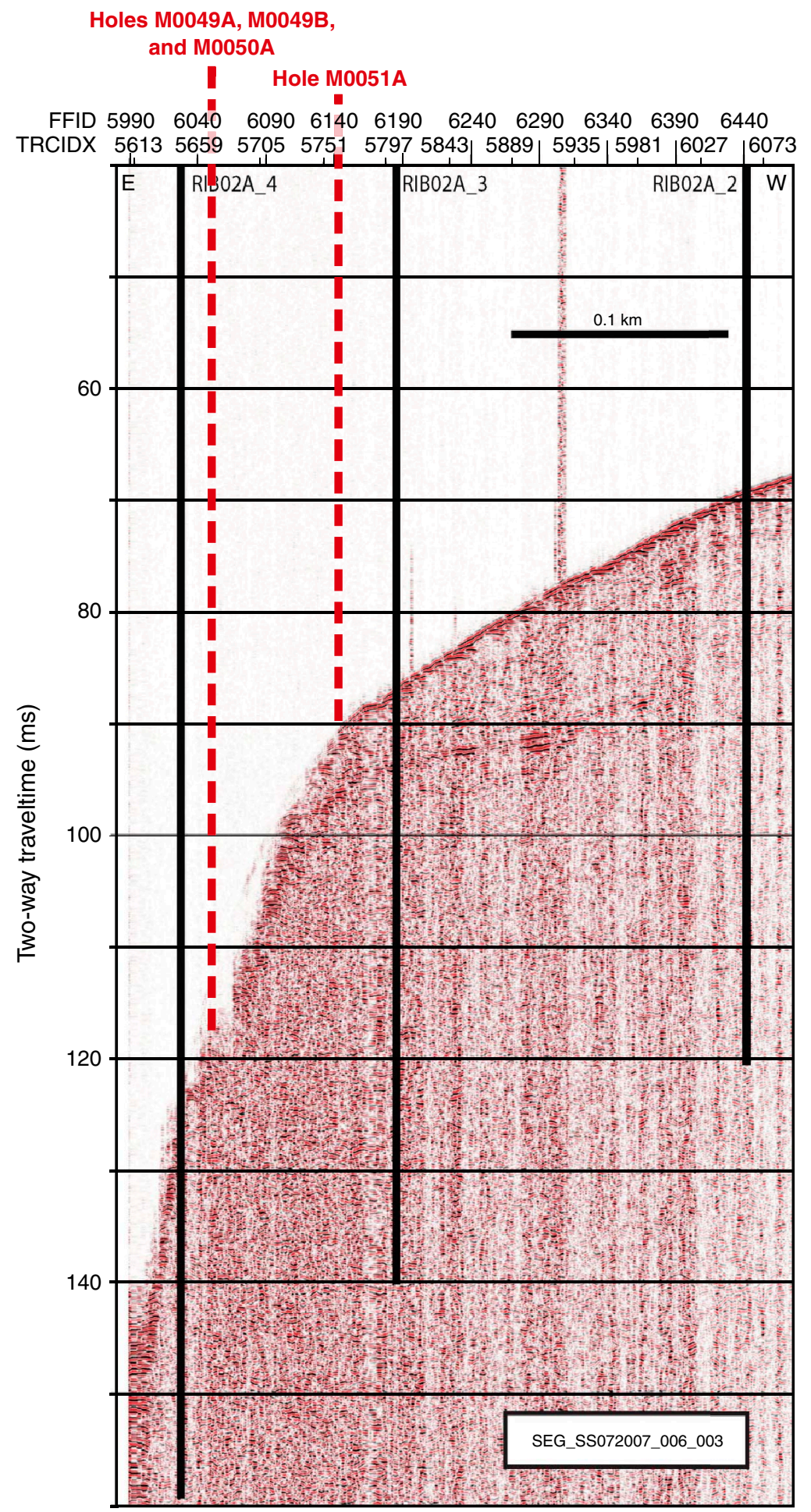


Figure F8. Enlargement of Figure F1 in the "Transect RIB-02A chapter" showing Holes M0049A-M0051A at transect RIB-02A, Expedition 325. EPSP = Environmental Protection and Safety Panel, GBRMPA = Great Barrier Reef Marine Park Authority.

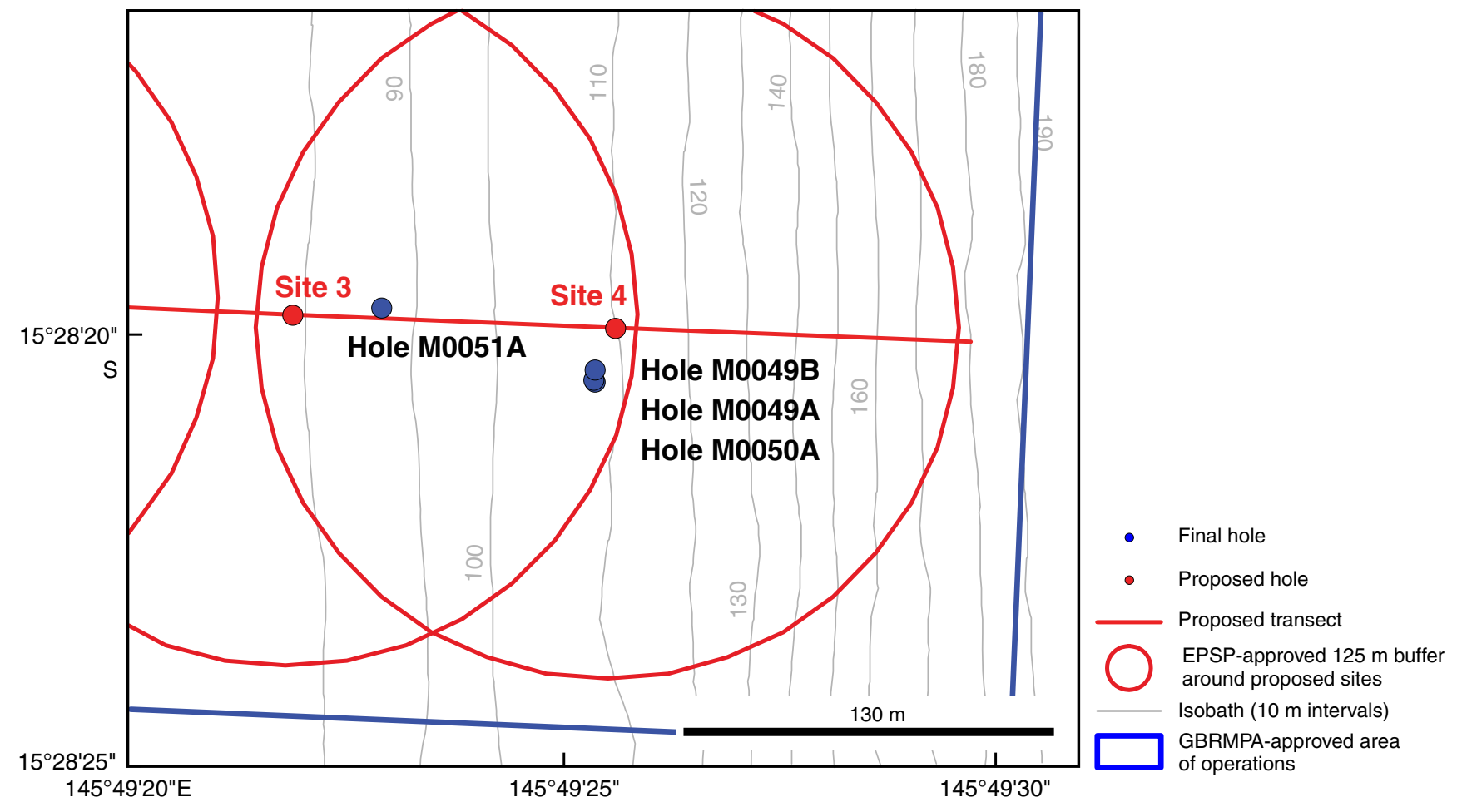


Figure F9. Topas PS18 seismic profile SEG_SS072007_012_012 showing location of proposed drill sites at transect NOG-01B, Expedition 325. Approximate location of seismic profile is shown in Figure F1 in the "Transect NOG-01B" chapter (proposed transect). Red lines = actual drill locations, solid lines $=$ holes drilled on the seismic profile transect, dashed lines $=$ holes drilled off the seismic profile transect.

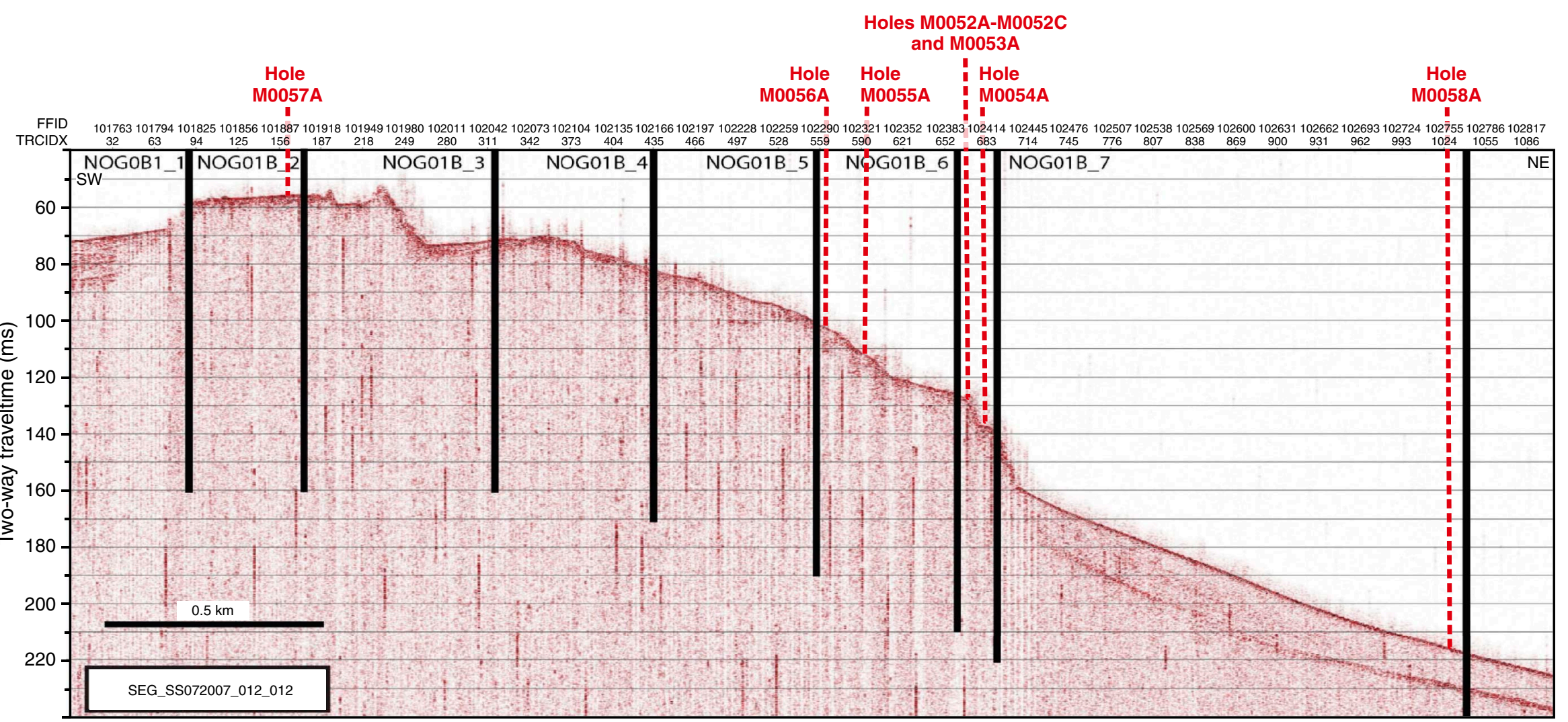


Figure F10. Enlargement of Figure F1 in the "Transect NOG-01B" chapter showing Holes M0052A-M0056A at transect NOG-01B, Expedition 325. EPSP $=$ Environmental Protection and Safety Panel, GBRMPA $=$ Great Barrier Reef Marine Park Authority.

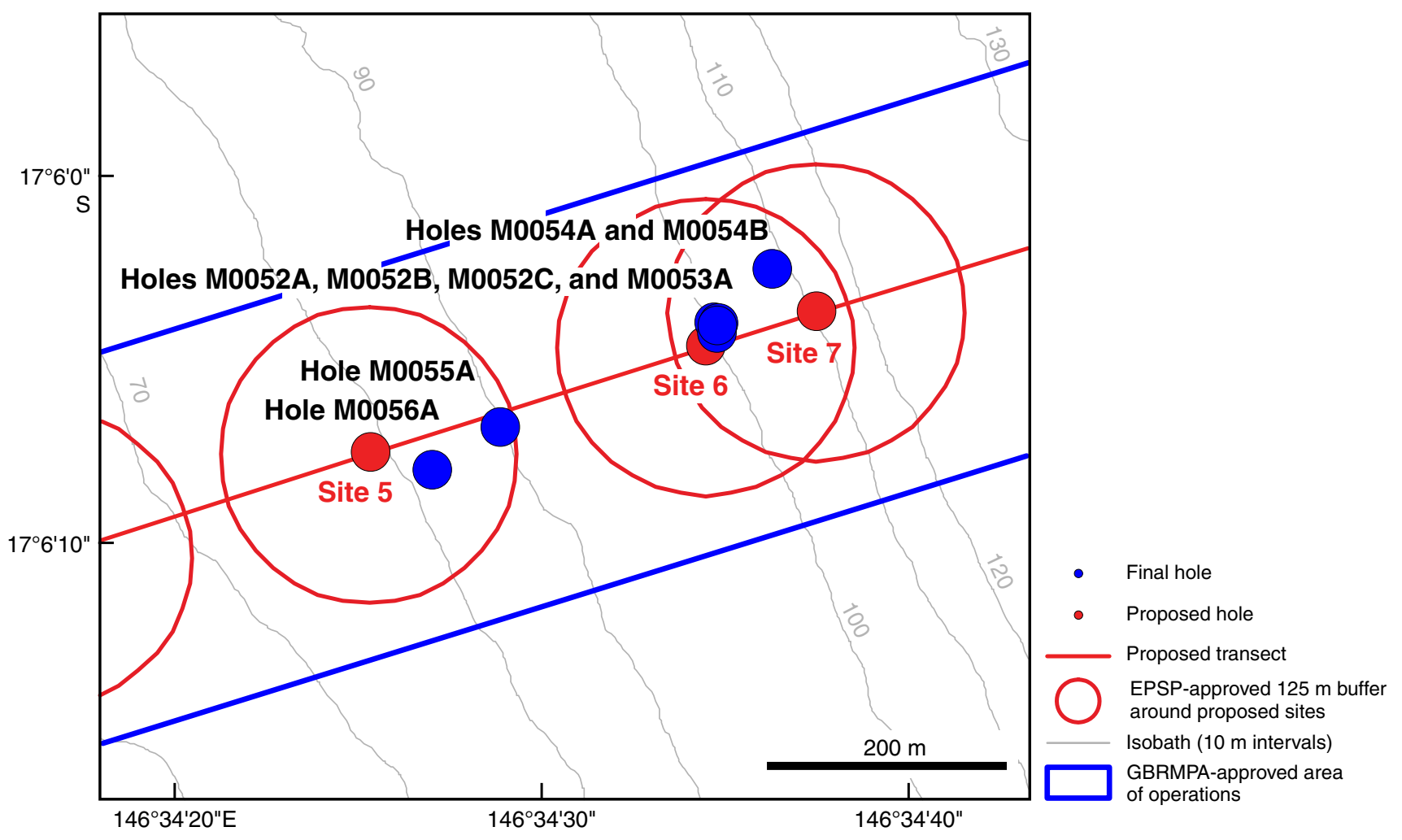


Figure F11. Histogram showing preliminary radiometric ages determined from chronology on core catcher materials recovered during Expedition 325. Age distribution clearly indicates that the recovered fossil coral reef cores span key periods of interest for sea level change and environmental reconstruction, including Heinrich Events 2 and 1 (H2 and H1), the Last Glacial Maximum (LGM), Bølling-Allerød (B/A), and Younger Dryas (YD). Previously published data on relative sea level from 20 cal y BP to the present (upper symbols) along with GISP2 $\delta^{18} \mathrm{O}$ (proxy for temperature over Greenland, black line) are plotted for comparison. MWP-1A = meltwater pulse 1A. Source of data: Tahiti = Bard et al. $(1996,2010)$; Huon Peninsula = Chappell and Polach (1991), Edwards et al. (1993), Yokoyama et al. (2001a, 2001b); Huon drill core = Cutler et al. (2003); Sunda shelf = Hanebuth et al. (2000); Barbados = Fairbanks (1989), Bard et al. (1990); GISP2 = Stuiver and Grootes (2000). MIS = marine isotope stage.

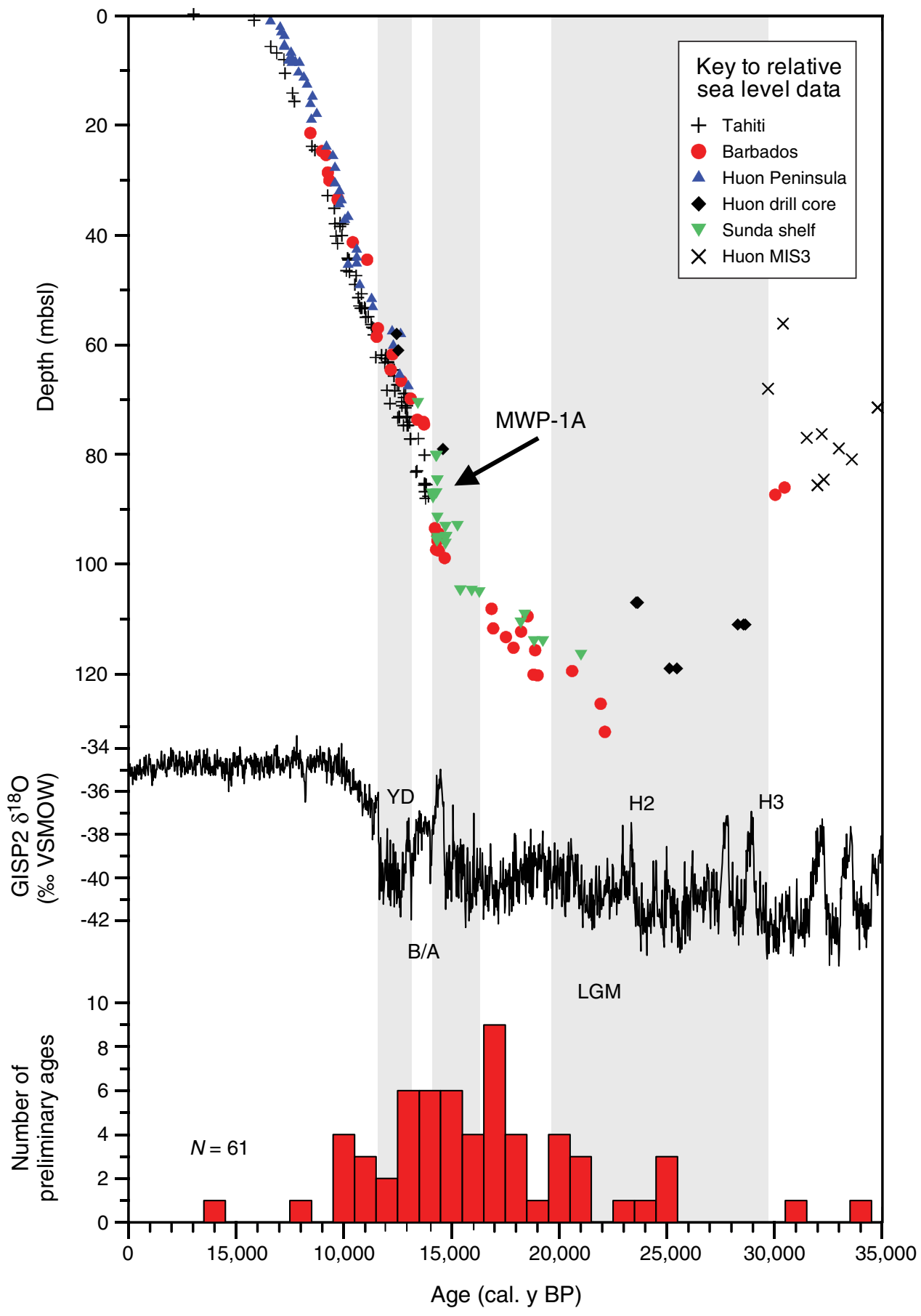


Table T1. Coring summary, Expedition 325. (See table notes.)

\begin{tabular}{|c|c|c|c|c|c|c|c|c|c|c|c|}
\hline \multirow[b]{2}{*}{ Hole } & \multirow[b]{2}{*}{ Latitude } & \multirow[b]{2}{*}{ Longitude } & \multicolumn{2}{|c|}{ Water depth $(\mathrm{m})$} & \multirow[b]{2}{*}{$\begin{array}{l}\text { Number } \\
\text { of runs }\end{array}$} & \multirow[b]{2}{*}{$\begin{array}{c}\text { Interval } \\
\text { cored }(m)\end{array}$} & \multirow{2}{*}{$\begin{array}{l}\text { Core } \\
\text { recovered } \\
(\mathrm{m})\end{array}$} & \multirow{2}{*}{$\begin{array}{l}\text { Core } \\
\text { recovery } \\
(\%)\end{array}$} & \multirow{2}{*}{$\begin{array}{l}\text { Penetration } \\
\text { depth } \\
\text { DSF-A (m) }\end{array}$} & \multirow{2}{*}{$\begin{array}{l}\text { Hole } \\
\text { recovery } \\
(\%)\end{array}$} & \multirow[b]{2}{*}{$\begin{array}{c}\text { Time on } \\
\text { site (days) }\end{array}$} \\
\hline & & & EM300 & $\begin{array}{l}\text { Drill } \\
\text { string }\end{array}$ & & & & & & & \\
\hline \multicolumn{12}{|l|}{$325-$} \\
\hline M0030A & $19.6819^{\circ} \mathrm{S}$ & $150.2379^{\circ} \mathrm{E}$ & 83.5 & 85.0 & 2 & 6.00 & 0.24 & 4.00 & 6.00 & 4.00 & 0.85 \\
\hline M0030B & $19.68188^{\circ} \mathrm{S}$ & $150.23791^{\circ} \mathrm{E}$ & 83.5 & 85.0 & 3 & 9.00 & 0.55 & 6.11 & 9.00 & 6.11 & 0.40 \\
\hline M0031A & $19.67895^{\circ} \mathrm{S}$ & $150.23961^{\circ} \mathrm{E}$ & 90.1 & 92.0 & 17 & 43.00 & 5.68 & 13.21 & 43.00 & 13.21 & 2.09 \\
\hline M0032A & $19.678836^{\circ} \mathrm{S}$ & $150.239666^{\circ} \mathrm{E}$ & 91.9 & 93.0 & 20 & 36.70 & 5.99 & 16.32 & 36.70 & 16.32 & 1.15 \\
\hline M0033A & $19.678886^{\circ} \mathrm{S}$ & $150.239862^{\circ} \mathrm{E}$ & 91.3 & 91.5 & 23 & 32.80 & 13.41 & 40.88 & 32.80 & 40.88 & 1.15 \\
\hline M0034A & $19.69226^{\circ} \mathrm{S}$ & $150.230254^{\circ} \mathrm{E}$ & 51.0 & 55.0 & 16 & 23.10 & 6.71 & 29.05 & 23.10 & 29.05 & 3.19 \\
\hline M0035A & $19.672637^{\circ} \mathrm{S}$ & $150.243834^{\circ} \mathrm{E}$ & 100.1 & 103.0 & 23 & 29.90 & 12.23 & 40.90 & 29.90 & 40.90 & 2.98 \\
\hline M0036A & $19.672398^{\circ} \mathrm{S}$ & $150.243964^{\circ} \mathrm{E}$ & 103.2 & 103.0 & 22 & 34.00 & 8.91 & 26.21 & 34.00 & 26.21 & 1.77 \\
\hline M0037A & $19.670749^{\circ} \mathrm{S}$ & $150.246265^{\circ} \mathrm{E}$ & 122.3 & 129.2 & 14 & 21.00 & 7.52 & 35.81 & 21.00 & 35.81 & 0.83 \\
\hline M0038A & $19.671602^{\circ} \mathrm{S}$ & $150.244904^{\circ} \mathrm{E}$ & 107.0 & 108.6 & 1 & 1.50 & 0.18 & 12.00 & 1.50 & 12.00 & 0.53 \\
\hline M0039A & $19.671595^{\circ} \mathrm{S}$ & $150.244888^{\circ} \mathrm{E}$ & 107.0 & 108.6 & 21 & 28.40 & 10.39 & 36.58 & 28.40 & 36.58 & 1.02 \\
\hline M0040A & $19.796286^{\circ} \mathrm{S}$ & $150.481417^{\circ} \mathrm{E}$ & 126.1 & 132.7 & 12 & 21.50 & 11.73 & 54.56 & 21.50 & 54.56 & 0.61 \\
\hline M0041A & $19.796324^{\circ} \mathrm{S}$ & $150.481503^{\circ} \mathrm{E}$ & 126.6 & 132.7 & 12 & 22.10 & 10.06 & 45.52 & 22.10 & 45.52 & 0.55 \\
\hline M0042A & $19.84398^{\circ} \mathrm{S}$ & $150.44803^{\circ} \mathrm{E}$ & 50.8 & 56.3 & 29 & 46.40 & 10.94 & 23.58 & 46.40 & 23.58 & 2.19 \\
\hline M0043A & $19.798851^{\circ} \mathrm{S}$ & $150.479365^{\circ} \mathrm{E}$ & 102.9 & 107.9 & 23 & 35.00 & 6.04 & 17.26 & 35.00 & 17.26 & 0.85 \\
\hline M0044A & $19.798453^{\circ} \mathrm{S}$ & $150.479617^{\circ} \mathrm{E}$ & 105.3 & 104.1 & 9 & 11.00 & 1.67 & 15.18 & 11.00 & 15.18 & 0.72 \\
\hline M0045A & $19.798421^{\circ} \mathrm{S}$ & $150.479609^{\circ} \mathrm{E}$ & 105.3 & 105.0 & 4 & 14.60 & 0.00 & 0.00 & 14.60 & 0.00 & 0.24 \\
\hline M0046A & $19.798468^{\circ} \mathrm{S}$ & $150.479625^{\circ} \mathrm{E}$ & $117.5^{*}$ & $120.4^{*}$ & 11 & 20.40 & 2.52 & 12.35 & 20.40 & 12.35 & 0.45 \\
\hline M0047A & $19.799752^{\circ} \mathrm{S}$ & $150.478853^{\circ} \mathrm{E}$ & 99.1 & 100.5 & 14 & 33.20 & 3.79 & 11.42 & 33.20 & 11.42 & 0.56 \\
\hline M0048A & $19.801176^{\circ} \mathrm{S}$ & $150.477653^{\circ} \mathrm{E}$ & 97.5 & 102.3 & 4 & 7.10 & 0.69 & 9.72 & 7.10 & 9.72 & 0.28 \\
\hline M0049A & $15.472375^{\circ} \mathrm{S}$ & $145.823698^{\circ} \mathrm{E}$ & 97.6 & 98.6 & 2 & 3.50 & 0.77 & 22.00 & 3.50 & 22.00 & 0.24 \\
\hline M0049B & $15.472372^{\circ} \mathrm{S}$ & $145.823694^{\circ} \mathrm{E}$ & 97.6 & 100.0 & 13 & 15.60 & 2.79 & 17.88 & 15.60 & 17.88 & 0.52 \\
\hline M0050A & $15.472337^{\circ} \mathrm{S}$ & $145.823697^{\circ} \mathrm{E}$ & 97.6 & 98.2 & 6 & 10.50 & 1.87 & 17.81 & 10.50 & 17.81 & 0.27 \\
\hline M0051A & $15.472138^{\circ} \mathrm{S}$ & $145.823013^{\circ} \mathrm{E}$ & 78.1 & 80.9 & 2 & 2.50 & 0.15 & 6.00 & 2.50 & 6.00 & 0.35 \\
\hline M0052A & $17.101109^{\circ} \mathrm{S}$ & $146.576317^{\circ} \mathrm{E}$ & 97.6 & 103.7 & 1 & 1.40 & 1.30 & 92.86 & 1.40 & 92.86 & 0.25 \\
\hline M0052B & $17.101109^{\circ} \mathrm{S}$ & $146.576333^{\circ} \mathrm{E}$ & 97.6 & 103.7 & 4 & 6.90 & 0.46 & 6.67 & 6.90 & 6.67 & 0.30 \\
\hline M0052C & $17.101115^{\circ} \mathrm{S}$ & $146.576327^{\circ} \mathrm{E}$ & 97.6 & 106.8 & 2 & 1.90 & 0.10 & 5.26 & 8.80 & 5.26 & 0.22 \\
\hline M0053A & $17.101173^{\circ} \mathrm{S}$ & $146.576328^{\circ} \mathrm{E}$ & 97.9 & 104.6 & 33 & 37.30 & 12.18 & 32.65 & 37.30 & 32.65 & 1.59 \\
\hline M0054A & $17.1007^{\circ} \mathrm{S}$ & $146.576743^{\circ} \mathrm{E}$ & 107.2 & 110.3 & 6 & 9.30 & 2.23 & 23.98 & 18.72 & 11.91 & 1.06 \\
\hline M0054B & $17.1007^{\circ} \mathrm{S}$ & $146.576743^{\circ} \mathrm{E}$ & 107.2 & 110.3 & 12 & 27.84 & 8.25 & 29.63 & 33.20 & 24.85 & 2.26 \\
\hline M0055A & $17.101888^{\circ} \mathrm{S}$ & $146.5747^{\circ} \mathrm{E}$ & 87.3 & 93.1 & 10 & 28.50 & 10.00 & 35.09 & 31.29 & 31.96 & 0.89 \\
\hline M0056A & $17.102243^{\circ} \mathrm{S}$ & $146.574162^{\circ} \mathrm{E}$ & 81.2 & 85.6 & 16 & 40.20 & 12.73 & 31.67 & 41.29 & 30.83 & 1.05 \\
\hline M0057A & $17.105021^{\circ} \mathrm{S}$ & $146.563991^{\circ} \mathrm{E}$ & 42.3 & 47.7 & 16 & 40.60 & 19.00 & 46.80 & 41.78 & 45.48 & 1.30 \\
\hline M0058A & $17.097269^{\circ} \mathrm{S}$ & $146.58928^{\circ} \mathrm{E}$ & 167.1 & 172.4 & 15 & 41.40 & 33.94 & 81.98 & 41.40 & 81.98 & 1.06 \\
\hline
\end{tabular}

Notes: * = depth correction made because of drill pipe "skipping" down a pinnacle side for $10.8 \mathrm{~m}$ before finally penetrating the seafloor; applying the same correction gives $117.5 \mathrm{~m}$ instead of the previously expected $106.7 \mathrm{~m}$. EM300 = corrected EM300 echo sounder data, drill string $=$ drill string tagging seabed including predicted tidal variations. 
Table T2. Summary of descriptions and measurements made during Expedition 325. (See table notes.)

\begin{tabular}{ll}
\hline \multicolumn{1}{c}{ Greatship Maya, offshore GBR } & \multicolumn{1}{c}{ Onshore Science Party, Bremen } \\
\hline $\begin{array}{l}\text { Core description: } \\
\text { Core catcher description }\end{array}$ & $\begin{array}{c}\text { Core description: } \\
\text { Split-core visual core description }\end{array}$ \\
$\begin{array}{l}\text { Core photography: } \\
\text { Core catcher photography }\end{array}$ & $\begin{array}{c}\text { Discrete sample moisture and density properties: } \\
\text { Compressional P-wave velocity }\end{array}$ \\
Whole-core multisensor logging: & Bulk, dry, and grain density \\
Density & Water content \\
Velocity & Porosity \\
Magnetic susceptibility & Core photography: \\
Electrical resistivity & Photography of massive corals and their specialized splitting \\
Geochemistry: & Geochemistry: \\
pH by ion-specific electrode & IW analysis by ICP-OES (major and trace elements) \\
Alkalinity by single-point titration to pH & IC (chloride, bromide, sulfate, and nitrate) \\
Ammonium by flow injection method & Sediment TOC, TC, and TS by LECO (carbon-sulfur analyzer) \\
Salinity by refractometer & Sediment mineralogy by XRD \\
Downhole logging: & Micropaleontology: \\
Spectral natural gamma ray & Benthic foraminifers \\
Total natural gamma ray & Planktonic foraminifers \\
Full waveform sonic & Other: \\
Optical imaging & Thermal conductivity \\
Acoustic imaging & Color reflectance of split-core surface at discrete points \\
Caliper & Continuous digital line scanning of split-core surface \\
Magnetic susceptibility & CT scanning (selected cores only) \\
Electrical conductivity & Discrete paleomagnetic measurements \\
& Discrete magnetic susceptibility measurements \\
&
\end{tabular}

Notes: IW = interstitial water, ICP-OAES = inductively coupled plasma-optical emission spectrometry. IC = ion chromatography. TOC = total organic carbon, $\mathrm{TC}=$ total carbon, $\mathrm{TS}=$ total sulfur. $\mathrm{XRD}=\mathrm{X}$-ray diffraction. $\mathrm{CT}=$ computed tomography. 